Formas de apropriação da terra e reforma agrária: (im)possibilidades interculturais

TESE DE DOUTORADO

Orientador: Prof. Dr. Orlando Villas Bôas Filho.

UNIVERSIDADE DE SÃO PAULO

FACULDADE DE DIREITO

São Paulo-SP

2019 

ROSANGELA BARBOSA

\title{
Formas de apropriação da terra e reforma agrária: (im)possibilidades interculturais
}

\begin{abstract}
Tese apresentada a Banca Examinadora do Programa de PósGraduação em Direito, da Faculdade de Direito da Universidade de São Paulo, como exigência para obtenção do título de Doutor em Direito, na área de concentração de Filosofia e Teoria Geral do Direito, sob orientação do Prof. Dr. Orlando Villas Bôas Filho.
\end{abstract}

UNIVERSIDADE DE SÃO PAULO

FACULDADE DE DIREITO

São Paulo-SP

2019 
Autorizo a reprodução e divulgação total ou parcial deste trabalho, por qualquer meio convencional ou eletrônico, para fins de estudo e pesquisa, desde que citada a fonte.

Serviço de Processos Técnicos da Biblioteca da Faculdade de Direito da Universidade de São Paulo

\section{Barbosa, Rosangela}

Formas de apropriação da terra e reforma agrária: (im)possibilidades interculturais / Rosangela Barbosa. - São Paulo: USP / Faculdade de Direito, 2019.

$340 \mathrm{p}$.

Tese (Doutorado) - Programa de Pós-Graduação em Direito, Faculdade de Direito, Universidade de São Paulo, 2019.

Orientador: Orlando Villas Bôas Filho.

1. Antropologia jurídica. 2. Formas de apropriação da terra. 4. Função social da propriedade. 4. Pluralismo jurídico. 5. Reforma agrária. I. Villas Bôas Filho, Orlando, orient. II. Título. 
Nome: BARBOSA, Rosangela.

Título: Formas de apropriação da terra e reforma agrária: (im)possibilidades interculturais

Tese apresentada a Banca Examinadora do Programa de PósGraduação em Direito, da Faculdade de Direito da Universidade de São Paulo, como exigência para obtenção do título de Doutor em Direito, na área de concentração de Filosofia e Teoria Geral do Direito, sob orientação do Prof. Dr. Orlando Villas Bôas Filho.

Aprovado em:

Banca Examinadora

Prof. Dr. Orlando Villas Bôas Filho - Universidade de São Paulo (Orientador)

Prof. Dr. - Instituição (Banca Examinadora)

Prof. Dr. - Instituição (Banca Examinadora)

Prof. Dr. - Instituição (Banca Examinadora)

Prof. Dr. - Instituição (Banca Examinadora)

Prof. Dr. - Instituição (Banca Examinadora) 
"Minha Mamãe soberana Minha Floresta de joia Tu que dás brilho na sombra Brilhas também lá na praia Beija-Flor me mandou embora Trabalhar e abrir os olhos Estrela d'Água me molha Tudo que ama e chora Some na curva do rio Tudo é dentro e fora Minha Floresta de joia Tem a água tem a água tem aquela imensidão tem sombra da Floresta tem a luz do coração Bem-querer!!!” (Milton Nascimento) 

Aos povos da terra. 



\section{AGRADECIMENTOS}

A Deus.

Aos meus queridos pais, pelo amor incondicional, aos meus irmãos, pelo companheirismo na jornada da vida, e aos meus sobrinhos, pela esperança e alegrias.

Ao Professor Orlando Villas Bôas Filho, pela oportunidade, pelo incentivo, pela coragem inspiradora e por ter me proporcionado o privilégio de ser sua orientanda.

À Professora Valéria de Marcos, pelo aprendizado e pela generosidade.

À Professora Margarida Maria Moura, por ter me ensinado a escuta paciente que ouve o canto "da sabiá".

Às amigas Thaís e Alice, por nunca me deixarem duvidar da existência e do poder da amizade.

Às amigas Patrícia, Ilda e Rita, Ive, Tamara e Márcia, pelos cuidados e preocupações.

Aos amigos Pádua e Arthur, pelo incentivo e apoio.

Às colegas Márcia e Alessandra, que foram imprescindíveis para a finalização deste trabalho.

Aos funcionários da Secretaria de Meio Ambiente e Agricultura de Peruíbe - Thiago, Vivi e Rafael - e à estagiária Laís, pela compreensão e aprendizado diário.

Ao Diretor de Meio Ambiente da Secretaria de Meio Ambiente e Agricultura de Peruíbe - Marcelo Mouro -, pela disposição em assumir as atividades que se apresentaram inconciliáveis com as exigências deste trabalho.

Aos colegas João Scaramella, Ney Strozake e Guillaume e Arthur, pelos intermináveis diálogos e discussões que muito beneficiaram as reflexões sobre o tema.

Aos Procuradores Junior Divino Fidelis e Valdez Adriani Farias, que sempre se colocaram à disposição para que fosse possível conhecer o universo do INCRA. 

BARBOSA, Rosangela. Formas de apropriação da terra e reforma agrária: (im)possibilidades interculturais. 2019. 321 p. Tese (Doutorado). Faculdade de Direito, Universidade de São Paulo, São Paulo, 2019.

\section{RESUMO}

Este trabalho dedica-se à análise dos aportes oferecidos pela Antropologia Jurídica à compreensão da regulação jurídica das formas de apropriação da terra. A contribuição dessa área de estudo consiste nos postulados relativos às noções de alteridade, gênero humano, complexidade, diversidade, pluralidade das sociedades humanas e interculturalidade. $\mathrm{O}$ diálogo interdisciplinar entre os saberes antropológico e jurídico permite o descentramento crítico do monismo unitário das representações ocidentais acerca da regulação jurídica e das formas de apropriação da terra. A partir da noção de juridicidade, procura-se repensar o fenômeno jurídico e inscrever a regulação jurídica em uma perspectiva intercultural, enraizando-a nas múltiplas dimensões do social e no seu processo de reprodução. A análise pretendida serve-se também da tematização indicada pelo pluralismo jurídico para propor novas ideias em torno de outras experiências de juridicidade e de sua complexidade. Procura-se, com enfoque especial da teoria do multijuridismo de Étienne Le Roy, apresentar uma crítica à monolatria jurídica, propondo, para isso, não só a ruptura com as representações unitárias que entronizam o fenômeno jurídico na forma estatal, como também os fundamentos da juridicidade na imagem do tripé jurídico (tripode juridique). Os fundamentos de juridicidade são aportes para se compreender a pluralidade de regimes fundiários presentes na estrutura fundiária brasileira. Destaca-se, entre os problemas enfrentados no tema proposto, as implicações da proliferação da dimensão jurídica estatal na regulação dos modos de apropriação da terra que apresenta a tendência de desconsiderar as categorias autóctones, impondo a ideologia jurídica estatal e promovendo uma transformação ontológica no campo da juridicidade dos fundamentos das regulações jurídicas nativas. Busca-se evidenciar que a apropriação da terra se insere numa relação sociocultural e que a propriedade privada, apesar de ser derivada da apropriação, também se distingue daquela, em razão de seu regime jurídico, que repousa sobre as normas gerais e impessoais. Verifica-se que a regulação jurídica brasileira mobiliza, de maneira privilegiada, a propriedade privada da terra com um caráter absoluto e universal, mas que passa a se conformar aos interesses sociais a partir da institucionalização da função social da propriedade. Demonstra-se que, para o atendimento da função social da propriedade, compete ao Instituto Nacional de Colonização e Reforma Agrária (INCRA) a intervenção disciplinar, por meio do instituto expropriatório da propriedade privada, exercido sobre o imóvel rural, e a promoção da reforma agrária, nos termos constitucionais, utilizando-se, para isso, da implementação de projetos de assentamento que representam unidades territoriais com dimensão sociocultural. Com isso, constata-se que a pluralidade dos regimes jurídicos, presente nos assentamentos, é dilemática, na medida em que se relacionam e se confrontam formas de regulação jurídica da apropriação da terra, instituídas por grupos socioculturais com as estatizadas.

Palavras-chave: Antropologia Jurídica; formas de apropriação da terra; função social da propriedade; pluralismo jurídico; reforma agrária. 

BARBOSA, Rosangela. Means of land appropriation and land reform: (lack of) intercultural possibilities. 2019. 321 p. Thesis (Doctorate). Faculty of Law, University of São Paulo, São Paulo, 2019.

\begin{abstract}
This investigation dealt with the analysis of support offered by Legal Anthropology to base the understanding of legal regulation of land appropriation. In this area of study, the contribution consists of theory pertaining to the notions of alterity, human gender, complexity, diversity, human society plurality and intercultural studies. Cross disciplinary dialogue between anthropological and judicial knowledge allows for the critical de-centering of unitary monism of Western representations regarding legal regulation of land appropriation. Having the notion of jurisdicity as a starting point, we seek to rethink the juridical phenomenon and register legal regulation within an intercultural perspective, founded on the multiple social dimensions and on its reproduction process. The analysis that is sought here also uses the thematization indicated by legal pluralism so as to propose new ideas that surround other experiences of jurisdicity and of its very complexity. Focusing especially on the theory of multijurisdism (by Étienne Le Roy) we seek to present a critique on legal monolatry proposing, for this matter, not only a break with unitary representations that emphasize the state form of juridical phenomena, but also the fundaments of jurisdicity as legal tripod (tripode juridique). The jurisdicity bases are theories that enable us to understand the plural aspect of land regimes that exist in Brazilian land structure. Among the problems faced within this theme, the implications of the state proliferation dimension in the regulation of land appropriation. This approach has the tendency to overlook indigenous categories, imposing the state legal ideology and promoting an ontological transformation in the field of legal foundations for native juridical regulations. We seek to show that land appropriation is part of a sociocultural relation and that private property, despite being a product of appropriation differs from it, due to its legal regime, which rests on general and impersonal norms. We can see that the Brazilian legal regulation musters private property in a privileged manner, with an absolute and universal nature, but it starts to conform to social interests from the moment the social function of the property is institutionalized. It demonstrates that, in order to meet the social function, it is INCRA's (National Institute of Colonization and Land Reform) responsibility to intervene in a disciplinary manner, by means of the private property expropriation institute on rural real estate, and the promotion of land reform, as per the Constitution, implementing, for this matter, settlement projects that represent territorial units with sociocultural dimensions. Thus, we can see that the plurality of legal regimes that is present in settlement actions is dilemmatic since it is built on relationships and confrontations of legal regulations for land appropriation, which were instituted by sociocultural groups in tune with state enterprises.
\end{abstract}

Key-words: Legal Anthropology, land appropriation means, social function of property, juridical pluralism, land reform. 

BARBOSA, Rosangela. Forme di appropriazione e riforma agraria: (im)possibilità interculturali. 2019. 321 p. Tesi (Dottorato di Ricerca). Facoltà di Diritti, Università di São Paulo, São Paulo, 2019.

\section{RIASSUNTO}

Questo lavoro si dedica all'analisi degli apporti dall'Antropologia Giuridica per la comprensione della regolamentazione giuridica delle forme di appropriazione della terra. Il contributo di questo campo di studi consiste nei postulati riguardanti i concetti di alterità, genere umano, complessità, diversità, pluralità delle società umane a intercultura. Il dialogo interdisciplinare fra il sapere antropologico e quello giuridico permette la decentralizzazione critica del monismo unitario delle rappresentazioni occidentali della regolamentazione giuridica e delle forme di appropriazione della terra. A partire dalla nozione di giuridicità si cerca di ripensare il fenomeno giuridico e di inscrivere la regolamentazione giuridica in una prospettiva interculturale, fondandola sulle molteplici dimensioni del sociale e sul suo processo di riproduzione. L'analisi qui condotta si vale anche della tematizzazione indicata dal pluralismo giuridico per proporre nuove idee su altre esperienze di giuridicità e sulla loro complessità. Secondo l'approccio speciale della teoria del multigiuridismo di Étienne Le Roy, si presenta una critica alla monolatria giuridica e a questo scopo si propone non solo la rottura con le rappresentazioni unitarie che incensano il fenomeno giuridico nella forma statale, ma si offrono anche i fondamenti della giuridicità nell'immagine del tripode giuridico (tripode juridique). I fondamenti di giuridicità sono apporti per comprendere la pluralità dei regimi fondiari presenti nella struttura fondiaria brasiliana. Fra i problemi discussi nel tema proposto, emergono le implicazioni della proliferazione della dimensione giuridica statale sulla regolamentazione dei modi di appropriazione della terra che presenta la tendenza a non prendere in considerazione le categorie autoctone e impone l'ideologia giuridica statale oltre a promuove una trasformazione ontologica nel campo della giuridicità dei fondamenti delle regolamentazioni giuridiche native. Si cerca di sottolineare che l'appropriazione della terra si inserisce in un rapporto socioculturale e che la proprietà privata, sebbene sia derivata dall'appropriazione, si distingue da essa in virtù del suo regime giuridico che è fondato su norme generali e impersonali. Si verifica che la regolamentazione giuridica brasiliana considera in modo privilegiato la proprietà privata della terra con un carattere assoluto e universale, ma si conforma anche agli interessi sociali mediante l'istituzionalizzazione della funzione sociale della proprietà. Si dimostra che per mettere in pratica la funzione sociale della proprietà spetta all'Instituto Nacional de Colonização e Reforma Agrária - INCRA l'intervento disciplinare mediante l'istituto dell'espropriazione della proprietà privada applicato agli immobili rurali e alla promozione della riforma agraria, in termini costituzionali, valendosi, a questo fine, della realizzazione di progetti di distribuzione della terra che rappresentino unità territoriali con dimensioni socioculturali. Con ciò si dimostra che la pluralità dei regimi giuridici presente nella distribuzione della terra è dilemmatica, dato che sono messe in rapporto e a confronto con le forme statalizzate forme di regolamentazione giuridica dell'appropriazione della terra istituite da gruppo socioculturali.

Parole Chavie: Antropologia Giuridica; forme di appropriazione della terra; funzione sociale della proprietà; pluralismo giuridico; riforma agraria. 



\section{SUMÁRIO}

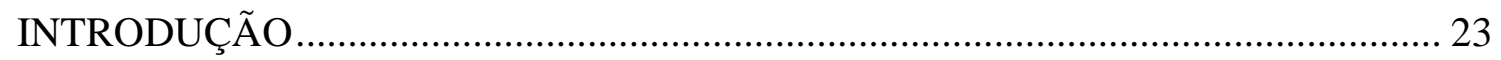

1 APORTES DA ANTROPOLOGIA JURÍDICA E A PLURALIDADE DAS

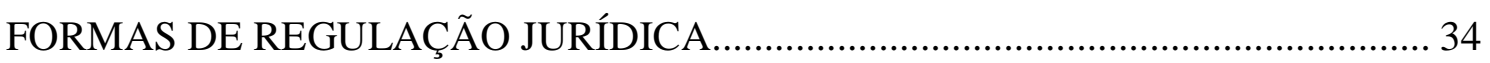

1.1 A LEITURA ANTROPOLÓGICA............................................................. 34

1.1.1 O campo de constituição de análise e de pesquisa da Antropologia ........ 34

1.1.2 A Antropologia como instrumento de compreensão sobre a interculturalidade

1.1.3 Modernidade: imposição da monolatria, do uno e da visão unitarista ..... 47

1.2 ANTROPOLOGIA JURÍDICA E A PLURALIDADE DAS FORMAS DE

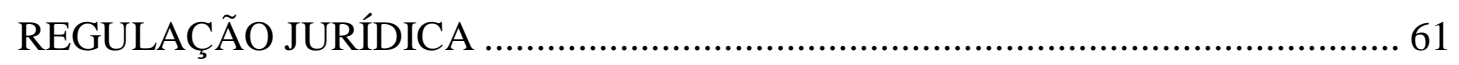

1.2.1 Pluralidade das formas de regulação jurídica e juridicidade .................... 61

1.2.2 Pluralismo jurídico e interculturalidade ............................................. 81

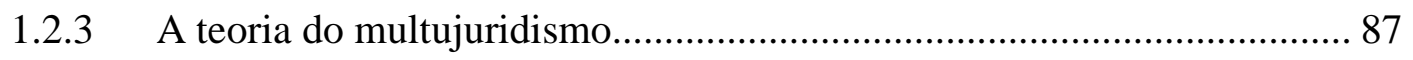

1.2.3.1 Os fundamentos de juridicidade inerentes à diversidade cultural - o tripé jurídico.

1.2.3.1.1 O fundamento de juridicidade do Ocidente: o império da norma geral e impessoal e o ordenamento imposto

2 APROPRIAÇÃO DA TERRA E DIVERSIDADE SOCIOCULTURAL ............ 107

2.1 DIVERSIDADE DAS FORMAS DE APROPRIAÇÃO DA TERRA........... 107 


\subsection{A DIVERSIDADE SOCIOCULTURAL DA ESTRUTURA FUNDIÁRIA}

BRASILEIRA.

\subsection{A JURIDICIDADE DA APROPRIAÇÃO DA TERRA DA ESTRUTURA} FUNDIÁRIA BRASILEIRA.

2.3.1 O arranjo de juridicidade da apropriação da terra da estrutura fundiária brasileira

3 APROPRIAÇÃO DA TERRA E PROPRIEDADE PRIVADA

3.1 PROPRIEDADE PRIVADA DA TERRA

3.1.1 Propriedade privada: da estrutura e da organização de uma sociedade voltada para o indivíduo e para o mercado

3.1.2 A norma geral e impessoal (NGI): justificativas para a consagração da propriedade privada como forma de apropriação da terra

3.2 PROPRIEDADE PRIVADA DA TERRA NO BRASIL

3.2.2 A institucionalização da propriedade privada como forma de apropriação da terra no Brasil

3.2.3 A propriedade privada absoluta no Código Civil de 1916 191

3.3 A FUNÇÃO SOCIAL DA PROPRIEDADE RURAL 199

3.3.1 Transformações funcionais da propriedade privada rural 199

3.3.2 A função social da propriedade rural e seu marco constitucional 219

3.3.3 As dimensões da função social da propriedade rural 231

4 REFORMA AGRÁRIA

4.1 REFORMA AGRÁRIA: CONCEITUAÇÃO; CONTEXTO DE 1964 A 1988 NO BRASIL - DISPUTAS E PROPOSTAS

\subsection{A LUTA PELO ACESSO À TERRA: OS IMPASSES NO PROCESSO}

CONSTITUINTE DE 1988 E A NOVA ORDEM POLÍTICA 260

\subsection{INSTITUTO NACIONAL DE COLONIZAÇÃO E REFORMA AGRÁRIA -} INCRA.

4.3.1 Instituto Nacional de Colonização e Reforma Agrária - INCRA: o poder instituído para implementar a reforma agrária 
4.3.2 Desapropriação da propriedade privada rural para fins de reforma agrária por

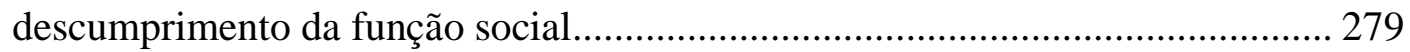

4.3.2.1 Desapropriação da propriedade rural por descumprimento da função social: disputas para a prevalência de um sentido puramente economicista. 281

4.4 ASSENTAMENTOS RURAIS: DISTRIBUIÇÃO DA TERRA E FORMAS DE REPRODUÇÃO DA VIDA SOCIOCULTURAL .......................................... 288

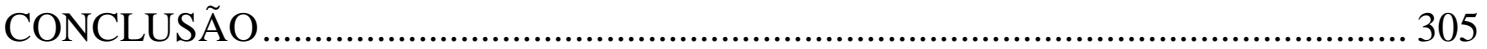

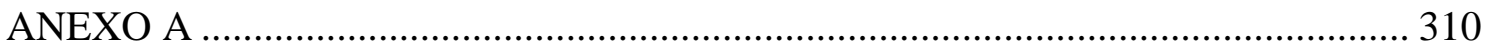

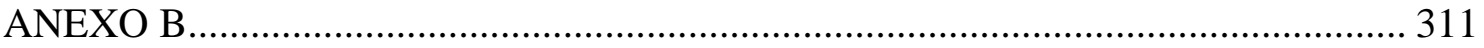

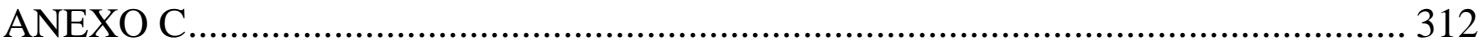

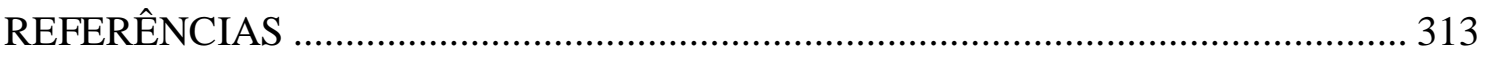





\section{INTRODUÇÃO}

Este trabalho inscreve-se no campo do Direito, considerando a possível e produtiva intersecção com a área da Antropologia. A interação entre esses dois universos específicos e as suas convergências em nome de uma Antropologia Jurídica trazem importantes aportes para a compreensão das formas de regulação social, qualificáveis como jurídica, em relação ao tema da apropriação da terra, nos termos em que se estabelecem no contexto brasileiro.

Interessa-nos, portanto, construir um diálogo entre Direito e Antropologia - ainda incipiente e de escasso interesse no nosso meio acadêmico, mas ganhando preponderância -, para buscar, por intermédio dele, contribuir para o debate acerca do tema aqui proposto - a apropriação da terra -, na direção de propiciar a superação da perspectiva reducionista de tomar o fenômeno jurídico em sua dimensão unicamente normativa e/ou legal.

Esse investimento vale a pena, na medida em que as incursões mais abrangentes sobre a noção do fenômeno jurídico podem conduzir à análise dos mecanismos de produção das formas de regulação jurídica e a sua inscrição no conjunto de configurações do tecido social, abrangendo, nessa perspectiva, aquelas que se constituem na e pela terra.

A regulação jurídica imposta, de maneira integral, pelo Estado renega e colide com outras formas de manifestação do jurídico. Nessa perspectiva autoritária, a lei ganha prevalência na hierarquia de fontes do direito, apresentando-se como um modelo garantidor da implementação da ordem civilizatória, na figura do progresso. Fundamentada numa rede conceitual, teórica, axiológica e normativa dada pela modernidade, essa abordagem menospreza as diversas formas de percepção do mundo, de viver, de organizações, de identidades, de modos de inteligibilidade, reduzindo-as à lógica da unidade que embasa todas as grandes invenções da modernidade - o Estado, o mercado, o Direito, a soberania, a propriedade. Nesse contexto, elas estruturam a organização da sociedade, com base na representação do individualismo, do estadismo e, em especial, do capitalismo. 
Na perspectiva que assumimos neste trabalho, a relativização das representações e de categorias ocidentais permite a abertura da tradição jurídica ocidental à experiência intercultural e ao pluralismo jurídico. Ganha-se, com isso, a possibilidade de se repensar o fenômeno jurídico em um contexto social complexo e constitutivo de nossa contemporaneidade e a de se reconhecerem outras tradições jurídicas que são desprovidas da figura estatal.

Estamos sustentados, para essa crítica etnocêntrica, por autores que, ao recusarem o modo habitual de pensar a regulação jurídica, propõem um diálogo intercultural, fundado na exigência de se construírem relações entre culturas e cosmovisões radicalmente diferentes e irredutíveis, assinaladas por assimetrias sociais.

A crítica à concepção do fenômeno jurídico desenvolvida no quadro de referência da epistemologia ocidental e a análise do fenômeno jurídico em uma dimensão essencialmente intercultural são assumidas por Étienne Le Roy. O autor radicaliza as manifestações do pluralismo jurídico e, em se propondo a pensar o pluralismo jurídico de forma pluralista, apresenta a compreensão da regulação jurídica a partir da tese do multijuridismo, exemplificada com mais facilidade pela imagem do tripé jurídico (tripode juridique), baseado em três fundamentos: normas gerais e impessoais (NGI); modelos de conduta e de comportamento (MCC); e sistema de disposições duráveis (SDD).

Nos termos propostos pela teoria do multjuridismo, adota-se a juridicidade como uma categoria intercultural que considera as normas gerais e impessoais em interação complementar e processual com os outros fundamentos.

Dado esse quadro geral de nosso trabalho, cabe-nos indicar os objetivos específicos que norteiam a sua elaboração. De maneira particular, esta investigação pretende analisar os movimentos engendrados pelo Estado em relação ao tema da apropriação da terra, que o levam a absorver as diversas manifestações de juridicidade, presentes no tecido social, para consagrar a propriedade privada da terra e para institucionalizar uma "mentalidade proprietária", nos processos de ordenamento e reconhecimento territorial, em detrimento de outras formas de apropriação da terra e seus respectivos sistemas regulatórios, que apresentam diferentes concepções de inscrições espaciais. 
Essa tendência do Estado de reduzir a diversidade regulatória dos regimes fundiários segundo os cânones da lei acaba por privilegiar a lógica da propriedade privada, favorecendo o surgimento de confrontos com outras formas de representação e de apropriação da terra e seus arranjos de juridicidade presentes no tecido social.

O esforço de outros saberes científicos de inventariar os tipos de apropriação da terra traz contribuições não só para o debate teórico sobre a compreensão dos processos por meio dos quais grupos e pessoas acessam, apropriam, usam, controlam e atribuem significados à terra, como também para a contestação das pretensões invocadas pela economia política, focalizadas na existência de categorias e de valores pretensamente universais com ênfase no quadro da propriedade privada.

No cenário brasileiro, em diferentes épocas, o território foi organizado a partir do estabelecimento de relações assimétricas de poder, baseadas na lógica da dominação, na negação da pluralidade e das formas de regulação social e jurídica da vida dos povos nativos, que, atualmente, são denominados “povos tradicionais” pelo léxico estatal.

As diversas formas de percepção do mundo, de viver, de organizações, de identidades, de modos de inteligibilidade são reduzidas à lógica da unidade. Por ela, a terra se transforma em mercadoria e é concebida a partir da perspectiva da economia de mercado, sob a preponderância dos imperativos da racionalidade e do lucro. A terra transforma-se, assim, em propriedade privada, inserindo-se no universo individualista.

No Brasil, o direito de propriedade da terra manteve-se em toda a sua plenitude, e, somente com a Lei 4.504, de 30 de novembro de 1964, denominada Estatuto da Terra, foram propostos trabalhos sistematizados para o disciplinamento da propriedade da terra, instituindo-lhe uma hipoteca social, e para a elaboração dos fundamentos da lei de reforma agrária e das estratégias oficiais de política fundiária em termos de discurso oficial do governo.

No entanto, políticas fundiárias com caráter excludente e a implementação de um modelo de modernização da agricultura inviabilizaram a reforma agrária. O campo 
continuaria mantendo um quadro de profunda e endêmica tensão e de conflito social, marcado pela ocorrência da violência extremada.

De fato, o passado parece insistir no presente e manter as continuidades com origens remotas da época colônia: concentração de terras nas mãos de uma pequena parcela da população, produção voltada para a monocultura, pecuária extensiva e atendimento predominantemente voltado ao mercado exterior, exploração dos recursos naturais e dos estoques de energia, persistência de trabalho em condições análogas às da escravidão e relações sociais extremamente violentas.

Como resultado de um processo contraditório e repleto de embates travados no espaço político por forças em disputa, a Constituição Federal de 1988 introduziu prescrições normativas, com parâmetros hermenêuticos e com valores supremos do ordenamento jurídico, que abriram a possibilidade de se instituir uma modalidade especial de intervenção do poder público na esfera dominial privada: a desapropriação, para fins de reforma agrária, do imóvel rural que descumpre a função social da propriedade.

Além disso, o legislador pôs em relevo, de forma inédita, os parâmetros constitucionais dos significados atribuídos à função social da propriedade. Neste trabalho, será mobilizada a função social da propriedade rural, por ser uma noção central para a compreensão do instituto da reforma agrária.

Nesse marco jurídico-constitucional, a reforma agrária assume a função de uma política pública voltada ao cumprimento da função social da propriedade, cuja execução deve ser compatível com a política agrícola, a partir de uma interpretação sistemática da extensa constitucionalização de direitos e garantias fundamentais. Releva-se, nesse contexto, um cenário marcado por exigências formuladas a partir de lutas sociais e por contradições, conflitos, dilemas e tensões.

Pretendemos, diante dessa configuração, compreender como as distintas modalidades de apropriação da terra, presentes na estrutura fundiária brasileira, e seus fundamentos regulatórios passam a repousar sob um quadro de formalização da juridicidade atrelada ao modelo estatal que institucionaliza seu território na forma de Estado-nação com a valorização da propriedade privada. 
Em razão desse quadro de demandas e de justificativas que orienta a realização de nosso trabalho de pesquisa, consideramos fundamentais as discussões e análises acerca do debate proposto pelo pluralismo jurídico sobre as diversas formas de apropriação da terra. Essa busca pode indicar-nos importantes reflexões sobre os processos de representação que estão na base de toda cultura, e possibilidades de utilização dos aportes fornecidos pelo pluralismo jurídico para a emancipação da abordagem da regulação jurídica de suas referências etnocêntricas, unitárias e universalistas, e da elaboração de uma análise em termos de diálogo intercultural.

Essas proposições justificam a organização desta tese em quatro capítulos. Inicialmente, enfocamos o processo de superação dos obstáculos epistemológicos do locus de enunciação em que estão situadas a Antropologia e a Antropologia Jurídica essa derivada da primeira. Para isso, remontamos ao contexto europeu, da segunda metade do século XIX, em que se constata, no âmbito da construção do saber científico, a ideia da unidade psíquica de toda espécie humana. Trata-se de uma abordagem que tendia a reduzir as diferenças culturais a estágios históricos de um mesmo caminho evolutivo, e a definir como seu objeto aquele que vivia em uma sociedade culturalmente diferente da ocidental, considerado primitivo e selvagem.

A ruptura com a atitude etnocêntrica permitiu à Antropologia experimentar a redefinição de seu objeto, eixos e métodos, e assumir como seus postulados a alteridade, o gênero humano, a complexidade, a diversidade e a pluralidade das sociedades humanas e a interculturalidade.

O primeiro capítulo detém-se, ainda, à análise da arquitetura operada pela modernidade e sua linguagem científica, que conseguiram, de forma extraordinária, limitar o contexto pluralista das culturas à visão de mundo unitarista ou monológica, ao logocentrismo e ao antropocentrismo, com pretensão de universalidade.

As formas de exercício do poder político, a organização social, o fenômeno regulatório, as práticas sociais e o modelo econômico são fortemente assinalados por essa visão monológica totalizante do mundo. No domínio jurídico, o etnocentrismo ocidental 
consistirá em reconhecer como válida somente a visão jurídica que enraíza a regulação jurídica na sua configuração estatizada, sedimentada em normas jurídicas.

Para propor uma análise sobre esse traço essencial da modernidade e a sua problematização, mobilizamos as contribuições significativas apresentadas, em especial, por Étienne Le Roy, Robert Vachon, Christoph Eberhard, Raimundo Panikkar, Michel Alliot e Jacques Vanderlinden, Norbert Rouland, Orlando Villas Bôas Filho, Emmanuelle Piccoli, Geneviève Motard. São estudiosos que nos ajudam a aprofundar a convicção de que é necessário libertar a regulação jurídica do quadro ocidental de análise, no qual está aprisionado, e reconhecer o pluralismo intrínseco nas representações do fenômeno jurídico.

A noção do termo juridicidade será mobilizada para promover a ruptura com os modos habituais de pensar a regulação jurídica, reconhecendo-se outras formas de expressão - concretas e legítimas - do fenômeno jurídico, que emergem da pluralidade e da conjugação das culturas em situação de complexidade. Essa perspectiva impõe-nos a necessidade de estabelecermos uma conexão direta entre a regulação jurídica e os processos de reprodução social.

Além disso, destacamos, entre as tematizações propostas, a perspectiva intercultural do pluralismo jurídico, que, ao abandonar a crença no unitarismo, inscreve a regulação jurídica nas múltiplas dimensões do social e privilegia a abordagem dinâmica do fenômeno jurídico.

Assinalamos, ainda no primeiro capítulo deste trabalho, a nossa opção em relação à teoria do multijuridismo, conforme discutida por Étienne Le Roy, como sendo a mais propícia para os interesses de nossa pesquisa. $\mathrm{O}$ autor, ao se referir à imagem de regulações, apresenta, como já mencionamos, três fundamentos de juridicidade, não redutíveis ou hierarquizáveis mutuamente, denominados normas gerais e impessoais (NGI), modelos de conduta e de comportamento (MCC), e sistema de disposições duráveis (SDD). Todas as sociedades experimentam várias formas de articulação e de arranjo nas tradições, mas, conforme montagens específicas, de acordo com cada tradição. O Ocidente, como exemplo relevante, faz das normas gerais e impessoais (NGI) o quadro de formalização da juridicidade, privilegiando excessivamente o modo legal de enunciação da norma. 
Passamos para o segundo capítulo identificando, inicialmente, o potencial heurístico do termo "apropriação" para a nossa investigação. Por essa análise, constatamos que, pela organização empírica do espaço, o ser humano constrói relações com a terra que, ao recobrirem dimensões sociais e simbólicas, assumem um caráter plural, dinâmico e complexo, intimamente vinculado à noção de cultura. Essas diversificadas relações acabam por definir também diversificados modos de apropriação. O reconhecimento da imensa diversidade das modalidades de apropriação da terra, presente no pluralismo irredutível da realidade, permite a emancipação da visão etnocêntrica que, por ser enfatizada pela monolatria ocidental, gera uma representação geométrica do espaço e a valorização da propriedade privada.

Para demonstrar a pluralidade sociocultural presente na estrutura fundiária brasileira, será estabelecido o diálogo com outras ciências, acionando, para isso, alguns trabalhos empíricos clássicos que propuseram dados e análises substanciais sobre alguns grupos socioculturais, incorporados pelas formas estatizadas e inscritos em uma posição na lei como "comunidades tradicionais", "populações tradicionais" e "povos tradicionais", com seus respectivos "territórios tradicionais". Ressalte-se que nossa estrutura fundiária engendra uma diversidade de regimes fundiários, organizados em torno do território e suas categorias edificadas sob a figura do Estado-nação.

Outro elemento fundamental abordado no segundo capítulo refere-se à análise da capacidade de o Estado brasileiro, vocacionado ao monismo e instituído sob as bases da ideologia territorial de Estado-nação, lidar com a existência de diferentes modalidades de apropriação da terra, baseadas por arcabouços de juridicidade diferentes da regulação estatal. Dessa elaboração, resulta o processo de juridicização, compreendido como a proliferação da dimensão jurídica na regulamentação das relações sociais, com a imposição da normatização estatal, que importa em um processo complexo e ambivalente.

Destacamos, da produção científica realizada para as análises dos temas propostos no segundo capítulo, as pesquisas realizadas por Mauro William Barbosa de Almeida, Margarida Maria Moura, Carlos Rodrigues Brandão, Ellen F. Woortmann Lygia Sigaud, José de Souza Martins Maristela de Paula Andrade, Valéria de Marcos e Eduardo Viveiros, que se esmeram na análise de grupos do rural do Brasil. 
O terceiro capítulo localiza a propriedade privada no quadro referencial das grandes invenções da modernidade, considerando-se a implicação lógica com as noções de individuo, de Estado e de mercado, que organizam a sociedade ocidental. Enquanto o mercado moderno potencializa o individualismo, a moderna economia, com mercados autorregulados, promove a prevalência do econômico sobre todo o contexto social, tornando-se um princípio de organização social. Nessa abordagem, a terra transforma-se em mercadoria com utilidade econômica.

Para elucidarmos as diferenças entre apropriação e propriedade privada, enfrentamos a ideia de que a propriedade privada, em se transformando em expressão única do regime moderno de bens, é tutelada pela forma de regulação jurídica estatal que lhe dá força normativa, ancorando-se na concepção teórica da propriedade individualista. Essa "mentalidade proprietária" participa da transposição de instituições europeias para o Brasil que, baseada na lógica da dominação, da expulsão, do extermínio e da negação da pluralidade, desconsiderou as formas socioculturais e seus regimes fundiários nativos, o que gerou inúmeros conflitos fundiários. Reside aí a raiz de muitos de nossos problemas sociais e injustiça histórica.

Sem qualquer pretensão de esgotar a trajetória histórica da propriedade na sua inscrição no ordenamento jurídico brasileiro, relevamos, ainda no terceiro capítulo, as contribuições operadas pela Lei n. 601, de 18 de setembro de 1850, conhecida como a Lei de Terras, e pelo Código Civil de 1916, na criação de condições jurídicas para a regulamentação de novas categorias e de novas políticas fundiárias. São categorias e políticas que passaram a embasar a existência de novas noções jurídicas envolvendo formas de pertencimento da terra que legitimaram a propriedade privada da terra no Brasil.

Uma intervenção mitigadora dos poderes absolutos do indivíduo sobre o uso e a disposição do bem, dispensados pelo direito de propriedade, ocorrerá com as imposições constitucionais da Carta Fundamental de 1981. Contudo, elas não operam as alterações normativas viabilizadas pela Emenda Constitucional n. 10, aprovada em 9 de novembro de 1964, pela Constituição Federal de 1946, pela Lei 4.504, de 30 de novembro de 1964, que dispõe sobre o Estatuto da Terra, e pela Constituição Federal de 1988. Essa última promove transformações inéditas no ordenamento jurídico brasileiro quanto à redução do 
conceito de propriedade privada individual, por meio da ampliação do processo de juridicização no que se refere à funcionalização do direito de propriedade e à viabilidade de um projeto normativo de reforma agrária baseado na modificação do regime de posse e de uso da terra. Porém, procuramos enfatizar que a proliferação da dimensão jurídica na regulamentação das relações sociais, com a imposição dessa nova legislação, estabelecendo, dessa forma, novas categorias normativas para uso do Estado e da sociedade, não se deu fora de arenas de conflito, de luta, de disputas e de ambiguidades.

O terceiro capítulo focaliza, ainda, uma análise mais detalhada da noção da função social da propriedade, normatizada no capítulo III (Da Política Agrícola e Fundiária e da Reforma Agrária), título VII (Da Ordem Econômica e Financeira), da Constituição Federal de 1988 e nos balizamentos definidos pela Lei ${ }^{\circ} 8.629$, de 25 de fevereiro de 1993, que dispõe sobre a regulamentação dos dispositivos constitucionais relativos à reforma agrária. Essas referências normativas prescrevem, entre outros, os parâmetros dos significados atribuídos à função social da propriedade rural, considerada um aspecto basilar da política de Reforma Agrária.

As questões mobilizadas, nesse capítulo, abordam aspectos essenciais do pensamento de Étienne Le Roy, Robert Castel, Claudine Haroche, Louis Dumont Karl Polany, José de Souza Martins, Maurice Godelier, Alain Supiot, Christian Laval, Pietro Perlingieri, Fernando Pereira Sodero, Karl Renner, Emília Viotti da Costa, Márcia Maria Menendes Motta, Jean-Étienne-Marie Portalis, Regina Bruno, Clóvis Beviláqua, Orlando Gomes Keila Grinberg, Leonilde Servolo Medeiros, Manuel Diégues Júnior, José Gomes da Silva, Raymundo Laranjeira, Luiz Edson Fachin, Moacir Gracindo Soares Palmeira, José Afonso da Silva, Carlos Frederico Marés, Júnior Divino Fidelis, Grégoire Madjarian, Helmut Rittstieg, Maria Sarita Motta, Ligia Osorio Silva, Ruy Cirne Lima e Caio Prado Junior.

Por fim, à luz das considerações realizadas nos capítulos anteriores, o quarto capítulo analisa a reforma agrária, dando ênfase à sua capacidade de comportar diversas significações e de mobilizar um amplo espectro de grupos ativamente envolvidos nos processos de apropriação da terra, que se inserem em circunstâncias sociais e históricas determinadas. Para isso, destacamos a atividade congressual no processo constituinte da 
Constituição Federal de 1988, que, pela relevância evidente na transição democrática brasileira, propiciou um espaço de mediação razoável para que se instalasse um ambiente de disputa, em torno da inscrição na lei, dos temas que envolvem a reforma agrária. Neles, incluem-se função social da propriedade, desapropriação, indenização e política agrícola.

A partir da definiçãa dos padrões estabelecidos pelo constituinte para a regulação normativa fundiária, buscamos demonstrar como eles fixam parâmetros e passam a orientar a atividade administrativa do Instituto Nacional de Colonização e Reforma Agrária (INCRA). Trata-se de um órgão estatal com poder de intervir na estrutura fundiária, com vistas à implementação da reforma agrária, e que acumula múltiplos simulacros de tarefas administrativa e judicial.

No entanto, para os propósitos deste trabalho, procuramos destacar a existência de um poder coercitivo voltado para a regulação jurídica do ordenamento territorial nacional, visando à desapropriação de formas de apropriação da terra, definidas estatalmente, e à implementação de projetos de assentamento. Assinalamos, nesse sentido, a necessidade de o INCRA mobilizar um conjunto de instrumentos e normativas técnicas, produzido no campo de juridicidade estatal, para cumprir essas tarefas.

O processo de consolidação na terra em uma unidade territorial com caráter sociocultural, derivada da atuação burocrática estatal para a aplicação de projetos da reforma agrária, promove formas de (re)criação de modos de apropriação da terra. No entanto, esse processo não está isento de conflitos e tensões, em razão da confrontação dos fundamentos de juridicidade existentes entre uma estrutura fundiária heterogênea, complexa e plural, e a estatizada, vocacionada à instituição do espaço de maneira homogênea e orientada pelo monismo jurídico.

A produção do quarto capítulo embasou-se nas perspectivas teóricas elaboradas, em especial, por Manuel Diégues Júnior, José Eli Veiga, Leonilde Servolo de Medeiros, Ariovaldo Umbelino de Oliveira, Moacir Palmeira, José de Souza Martins, Sérgio Sauer, Adriano Pilatti, José Gomes da Silva, José Graziano da Silva, Valdez Adriani Farias, Sonia Maria Pessoa Pereira Bergamasco, Sérgio Pereira Leite, Delma Pessanha Neves, José de Souza Martins, Valéria de Marcos e Marcelo Fernando Terence. 
Em termos de considerações finais, este trabalho aponta para possibilidades de se promoverem, no mundo jurídico, descentramentos necessários em relação às categorias que sustentam a forma habitual e homogênea de se conceber o fenômeno jurídico. Pode, assim, favorecer a abertura para vivências que tenham no horizonte a inteligibilidade de outras culturas. Compartilha, ainda, com estudiosos e pesquisadores, fundamentos teóricos importantes para se analisarem a juridicidade e a sua relação com a pluralidade de formas de apropriação da terra.

Por outro lado, esta pesquisa, ao indicar o quão profícuo é o tema da reforma agrária, assinala a necessidade de se estender sua abrangência, considerando a possibilidade de, por exemplo, empreenderem-se estudos empíricos acerca das diversificadas formas com que se estabelece a relação o INCRA e os diversos grupos sociais com quais o instituto se envolve. Seria o caso de, nessa perspectiva de pesquisa, analisar, no cotidiano da luta na e pela terra, como se organizam outras formas de juridicidade, que não a hegemônica. 


\section{CONCLUSÃO}

Discorrer sobre a reforma agrária requer, antes de tudo, uma atribuição preambular: identificar a atualidade e a importância do tema, que não passa despercebido aos olhos argutos de quem deseja compreender a realidade social; constatar a capacidade de mobilização que o tema impõe em uma agenda social, acionando, com isso, diversos sujeitos sociais; reconhecer a pluralidade de noções e a polifonia de narrativas sobre o tema que, necessariamente, forjam o diálogo entre os interessados; e deflagrar a conflituosidade inerente à temática, dada justamente em razão das questões mencionadas anteriormente.

Tudo isso porque discorrer sobre reforma agrária implica (re)pensar e se conectar, no plano da experiência, com a energia que engendra e mantém a vida. Uma energia que foi traduzida por nós, neste trabalho, como a terra; o substrato material de existência e o recurso natural finito que serve de palco para viabilizar nascer e morrer, cultivar e colher, sofrer e alegrar, anoitecer e clarear, aprender e descobrir... e tudo recomeçar.

Nesse sentido, o primeiro capítulo explicitou não só que a humanidade é plural, como também que ela deve ser compreendida pela pluralidade que a constitui. De fato, a natureza e o tecido social não nos furtam dessa evidência: há uma pluralidade de objetos, conceitos, representações e significados particulares convivendo ao mesmo tempo no mundo, orientando o comportamento e organizando a experiência dos sujeitos.

Isso importa em reconhecer que a existência de múltiplos quadros de referência de uma sociedade complexa e dinâmica está intimamente ligada à alteridade e à nossa inscrição na transmodernidade, que exige rupturas com os marcos civilizatórios oferecidos pela modernidade.

Ainda, abrir-se para o plural impõe-nos reconhecer que os sujeitos de conhecimento partem, cada um, do seu próprio topos, do próprio enraizamento cultural, portando inteligibilidades radicalmente diferentes, e que uma abordagem intercultural para as questões da vida - a análise da interculturalidade - deve ser construída por esse ângulo. 
Por isso, empregamos, com o auxílio de Étienne Le Roy e de sua teoria, a inversão do iceberg, utilizado metaforicamente para se compreender o fenômeno jurídico. A teoria do multijuridismo devolve às formas de regulação jurídica nativas e invisibilizadas por relações assimétricas de poder a dignidade do seu estatuto regulatório jurídico, sem que, para isso, dissipe, também, considerando o mesmo estatuto, a forma estatizada de concepção do jurídico.

Em reforço às reflexões do primeiro capítulo, o segundo exemplificou, com experiências vivas, os matizes socioculturais do mundo e o caráter plural, dinâmico e complexo das dimensões do social. Com isso, comprovou que a lente monocromática, resultante da redutora e castradora mentalidade monológica ancorada na representação do uno, obscurece a compreensão do social e a experiência com a realidade.

E nesse projeto de pluralidade de formas de vida se configura a pluralidade de formas de apropriação da terra, que promove as múltiplas relações do ser humano com a terra e se constrói em processos forjadores de produção de identidade, singular e coletiva, constituidores de saberes e sentidos que amarram o ser humano nas teias de significados que ele mesmo teceu.

No entanto, essas mesmas relações do ser humano com a terra são marcadas por conflituosidades e violência e integram um conjunto de contradições, conflitos, dilemas e tensões da dinâmica social e sua regulação, incluindo a jurídica.

As causas dos conflitos fundiários são inúmeras. Elas percorrem o registro histórico da humanidade e dos mais diversos povos. Contudo, os conflitos contemporâneos estão, por certo, simbioticamente relacionados com o surgimento de uma economia de mercado que, além de reduzir as lógicas do social aos ditames mercantis, propõe paradigmas que persistem na tentativa de transformar, ficticiamente, os seres humanos e a natureza em mercadorias e submetê-los à lógica do mercado, que lhes determinam, inclusive, os preços.

Para essa abordagem, o terceiro capítulo trouxe contribuições analíticas e reflexivas importantes, ao apontar que esse novo padrão econômico exige a propriedade privada da terra e que ela se reforça pelo engendramento de uma mentalidade proprietária e pela tutela da regulação, que dá força normativa à concepção teórica da propriedade 
individualista, formulada em termos de atribuir à propriedade a ideia de manifestação interna do indivíduo e universal.

Também nesse sentido, os segundo, terceiro e quarto capítulos deram voz aos sujeitos submetidos a processos espoliatórios e expropriatórios que historicamente reivindicam a correção dos efeitos danosos do padrão de apropriação da terra persistente na estrutura agrária brasileira.

Com as incursões orientadas por marcos cronológicos, constatamos que a ordenação territorial brasileira ainda é fundada na prevalência da propriedade privada como forma de apropriação da terra. Desconsideram-se, portanto, outras formas que se inscrevem segundo códigos culturais próprios, regulados por montagens de arranjos de juridicidade com fundamento nos hábitos e no costume, que lhes dão o sentido e a possibilidade de continuidade do processo reprodutor da vida.

Assinalamos desse processo que o caráter concentrado da terra e a constituição da propriedade privada da terra à custa do patrimônio público se deram pelo consentimento do Poder Público, seja de maneira autorizativa, seja de forma omissiva.

Considere-se, ainda, nesse quadro, o trágico ciclo de violência no campo que registra perseguições, ameaças, assassinatos, extermínio, trabalho escravo, atividades periculosas ou insalubres, sem a adoção das cautelas necessárias e a exploração do trabalho infantil, uso intensivo de agrotóxicos e transgênicos como um padrão de plantio monocultural e voltado à exportação, destruição de ecossistemas, comercialização da vida biótica e dos seres abióticos. Esse padrão representa um bloqueio ao estabelecimento de diálogos diatópicos presididos por conexões de interculturalidade.

Por outro lado, o conflito também assume uma dimensão regulatória jurídica. Esse é um ponto que foi desenvolvido em todos os capítulos. As várias formas de articulação e de arranjo entre os fundamentos de juridicidade evidenciam uma assimetria relacional com a prevalência das normas gerais e impessoais. Além disso, a proliferação da dimensão jurídica na regulamentação das relações sociais, com a imposição da normatização estatal, tem a tendência de desconsiderar as categorias autóctones e, uma 
vez consideradas, promover uma transformação ontológica no campo da juridicidade dos fundamentos da regulação jurídica nativa.

Ainda no campo das contradições latentes das abordagens relativas à reforma agrária, que são inúmeras, os terceiro e quarto capítulos apresentaram contrapontos quanto à criação de categorias normativas para uso do Estado e da sociedade, capazes de permitir modalidades, antes impensáveis, e de promover a criação de subjetividades, novas moralidades e agenciamentos para a (re)criação de novas formas de apropriação da terra. Há, de alguma forma, a inserção de subcidadãos, sujeitos desqualificados, invisibilizados e historicamente excluídos da partilha dos bens sociais, na rede protetiva de direitos, incluindo o direito de propriedade.

Acrescenta-se a esse quadro não isento de ambiguidades, que o acesso à terra por meio de uma unidade territorial criada pelo INCRA, por mais que seja desenhada em diversos matizes, não escapa ao processo modelador do Estado que lhe impõe as lógicas da burocracia administrativa, mas que também se abre, na qualidade de unidade com dimensão sociocultural, às experiências organizativas do espaço, reguladas pelos modelos de condutas e de comportamentos (MCC) e os sistemas de disposições duráveis (SDD).

Por isso, os assentamentos instituídos pelo INCRA são profícuas oportunidades de registro do incessante processo (re)criador de espaços e modos de se apropriar da terra, um lócus anunciador de diálogos interculturais, de montagens de arranjos de juridicidade e de manifestação da diversidade sociocultural como característica instituída da vida.

Não é sem motivo que o INCRA se torna um órgão estratégico para a (não)promoção da reforma agrária: de um lado, o órgão estatal pode viabilizar alguma mudança nessa configuração social e política da ordenação territorial brasileira; por outro, também pode ser instrumentalizado por interesses políticos e econômicos dos terratenentes.

Ao finalizarmos este trabalho - o trabalho e não as nossas inquietações -, fica-nos a impressão de que ele pode contribuir para que pesquisadores proponham uma saudável - e recomendável - instabilidade no mundo jurídico. Acreditamos que esta nossa investigação suscita reflexões sobre descentramentos das categorias que informam a 
maneira habitual de se pensar e de se organizar a experiência do fenômeno jurídico. Nessa perspectiva, pode favorecer a abertura para vivências que tenham no horizonte a inteligibilidade de outras culturas.

Ainda em termos de contribuição, este trabalho compartilha fundamentos teóricos importantes para se pensarem a juridicidade e a sua relação com a pluralidade de formas de apropriação da terra. Além disso, permite a tematização da reforma agrária pela perspectiva da juridicidade.

Por certo, ele não esgota as possibilidades de análise de tema tão complexo, dinâmico, plural e intercultural como é a apropriação da terra. A compreensão dos regimes fundiários no Brasil, nos termos da temática proposta, pode ser ampliada se o diálogo com as referências teóricas acionadas neste trabalho tiverem o contato com a base empírica que permitiriam outras percepções sobre a reforma agrária e sobre a relação estabelecida entre o INCRA e os diversos grupos sociais.

A continuidade deste trabalho nessas bases identificaria narrativas ainda mais reais que confirmariam a hipótese de se imaginarem outros mundos possíveis. Se assim esta investigação for compreendida, terão valido a pena todos os esforços que ela exigiu desta pesquisadora. 
ANEXO A

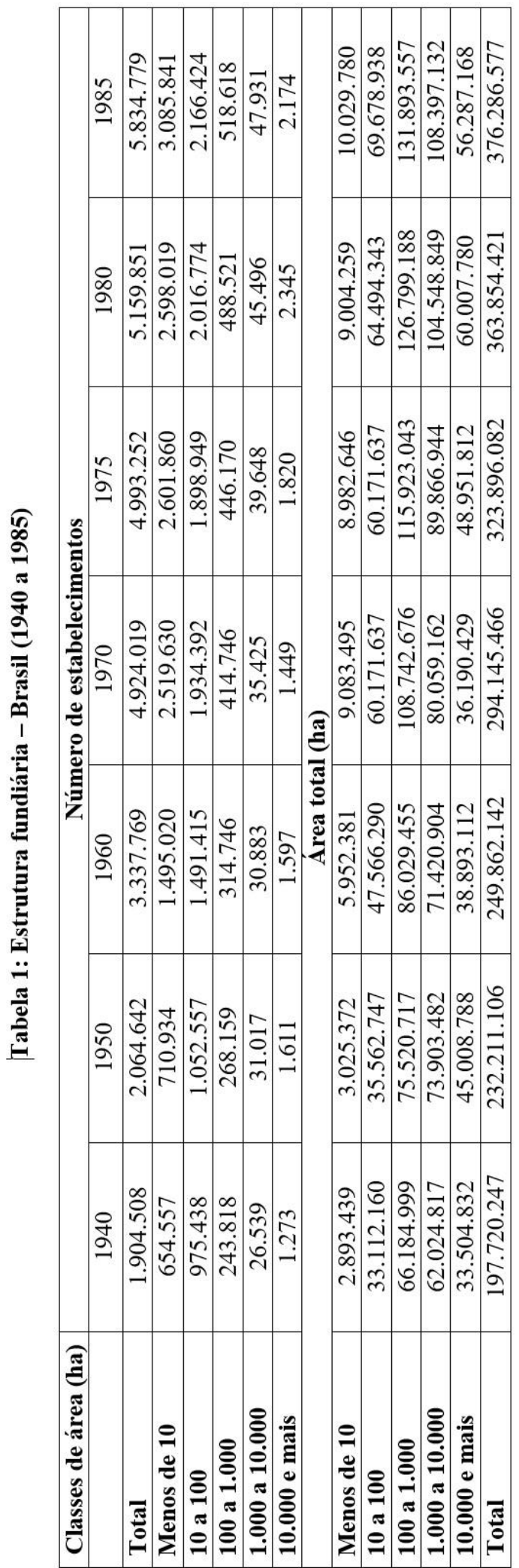


ANEXO B

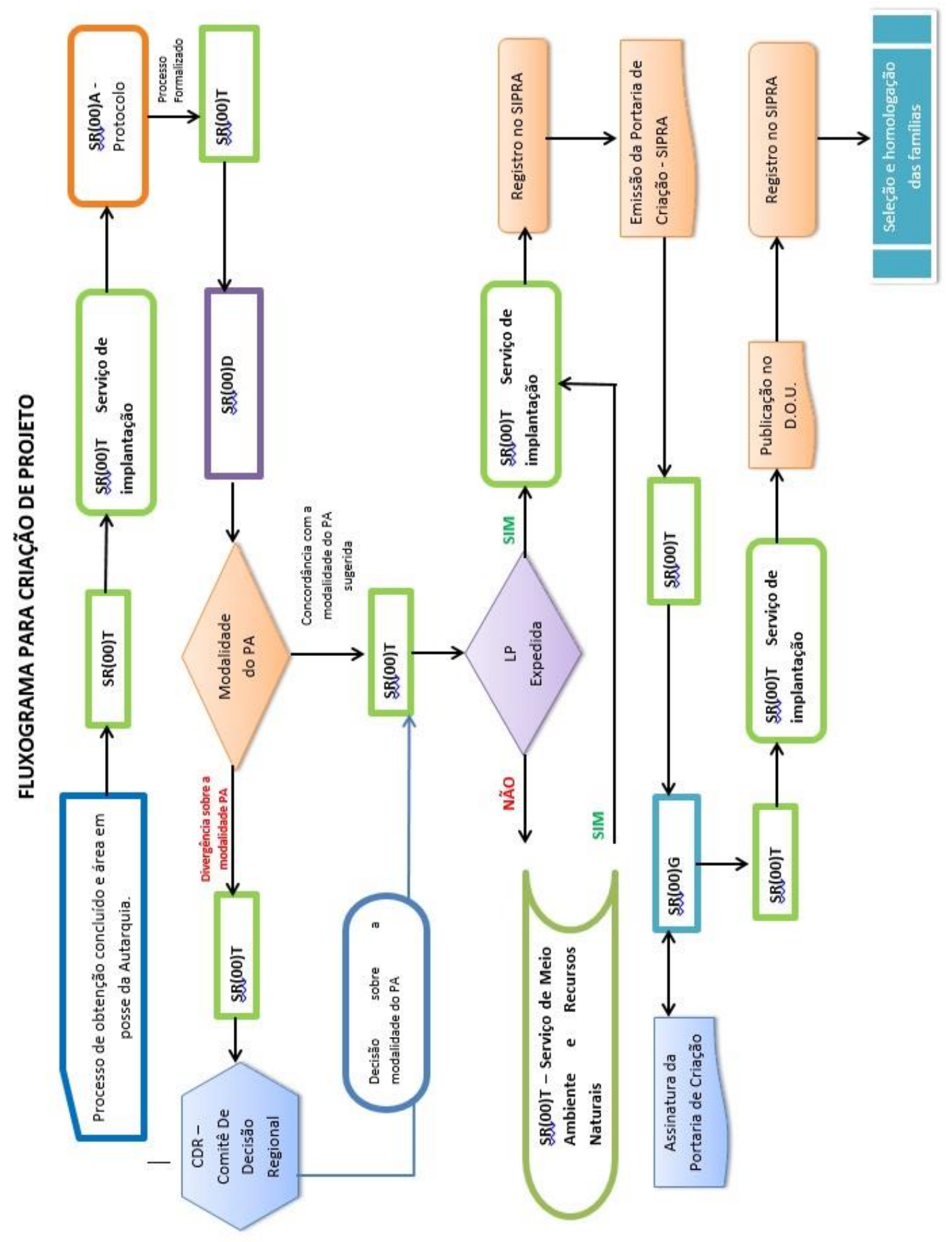


ANEXO C

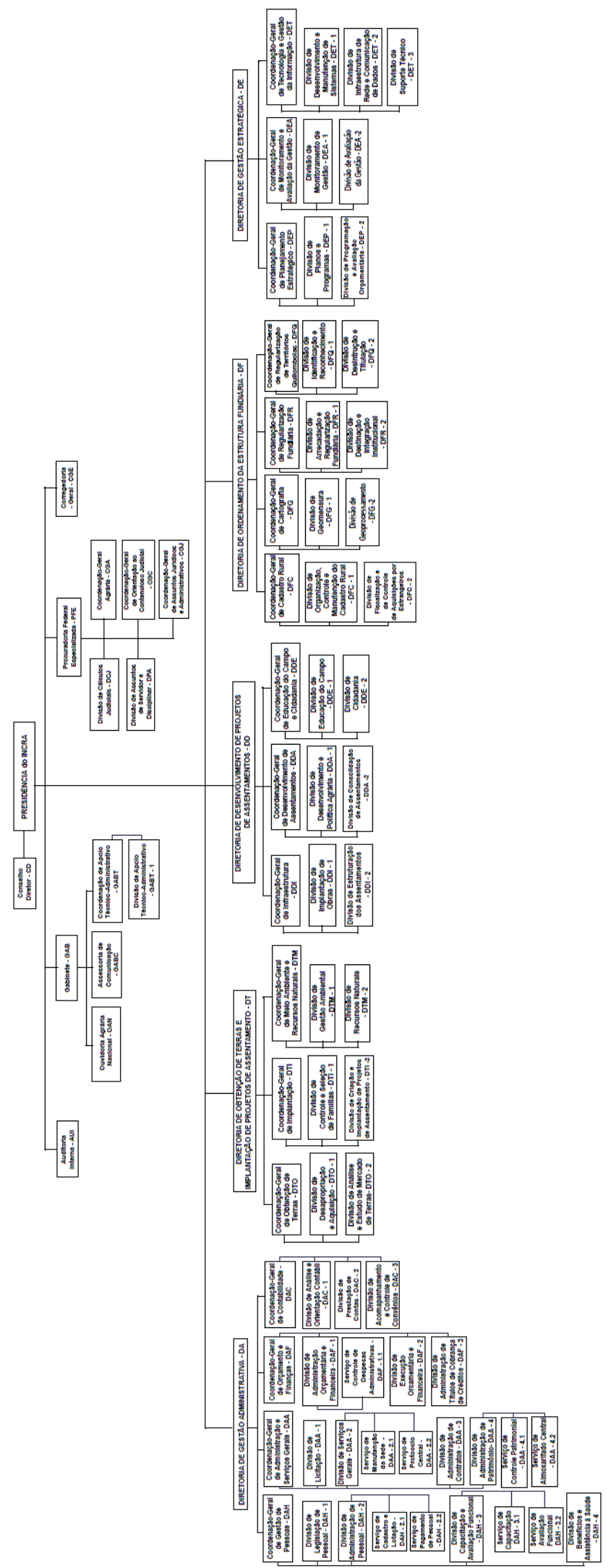




\section{REFERÊNCIAS}

ACOSTA, Alberto; GUDYNAS, Eduardo. La renovación de la crítica al desarrollo y el buen vivir como alternativa. Utopía y Praxis Latinoamericana, Zulia, Venezuela, v. 16, n. 53, p. 71-83, abr./jun. 2011. Disponível em: < https://www.redalyc.org/articulo.oa? $\underline{\mathrm{id}=27919220007}>$. Acesso em: 26 fev. 2019.

ADONON, Akuavi; PLANÇON, Caroline; EBERHARD, Christoph; Les cultures juridiques. In: CHRÉTIEN-VERNICOS, Geneviève; RUDE-ANTOINE, Edwige (dir.). Anthropologies et Droits. Etats des savoirs et orientations contemporaines. Paris: Dalloz, 2009, p. 205-243.

ALLIOT, Michel. L'État et la société en Afrique noire, greffes et rejets. Revue française d'histoire d'outre-mer, Paris, tome 68, n. 250-253, p. 95-99, 1981. Disponível em: < https://www.persee.fr/doc/outre_0300-9513_1981_num_68_250_2286 >. Acesso em: 6 fev. 2019.

Antropologia Jurídica. In: ARNAUD, André-Jean (Dir.). Dicionário enciclopédico de teoria e de sociologia do direito. Tradução de Patrice Charles, F. X. Willaume. 2. ed. Rio de Janeiro: Renovar, 1999. p. 45-47.

Introduction. In: KUYU, Camille (org.). Le droit et le service public au miroir de l'anthropologie. Paris: Éditions Karthala, 2003, p. 7-38.

Coutume et mythe. In: KUYU, Camille (org.). Le droit et le service public au miroir de l'anthropologie. Paris: Éditions Karthala, 2003, p. 39-53.

La méditerranée et le droit. In: KUYU, Camille (org.). Le droit et le service public au miroir de l'anthropologie. Paris: Éditions Karthala, 2003, p. 87-95.

Anthropologie et juristique. Sur les conditions de l'élaboration d'une Science du droit. In: KUYU, Camille (org.). Le droit et le service public au miroir de l'anthropologie. Paris: Éditions Karthala, 2003. p. 283-307.

L'anthropologie juridique et le droit des manuels. In: KUYU, Camille (org.). Le droit et le service public au miroir de l'anthropologie. Paris: Éditions Karthala, 2003. p. 307-320.

ALMEIDA, Alfredo Wagner Berno de. Terras tradicionalmente ocupadas. Processos de territorialização e movimentos sociais. Revista Brasileira de Estudos Urbanos e Regionais, São Paulo, v. 6, n. 1, p. 9-32, maio 2004. Disponível em: < http://www.geografia.fflch.usp.br/graduacao/apoio/Apoio/Apoio_Valeria/flg0563/1s201 5/102-172-2-PB.pdf >. Acesso em: 9 fev. 2019.

Terras de preto, terras de santo, terras de índio: uso comum e conflito. In:

GODOI, Emilia Pietrafesa de; MENEZES, Marilda Aparecida de; MARIN, Rosa 
Acevedo. (org.). Diversidade do campesinato: expressões e categorias: estratégias de reprodução social. 1. ed. São Paulo: Editora UNESP, 2009. v. 2. p. 39-66.

ALMEIDA, Mauro William Barbosa de. Narrativas Agrárias e a Morte do Campesinato. Ruris, Campinas, v. 1, n. 2, set. 2007. Disponível em: < https://www.ifch.unicamp.br/ ojs/index.php/ruris/article/view/656/523 >. Acesso em: 9 fev. 2019.

ALMEIDA, Mauro W. Barbosa de; REZENDE, Roberto Sanches. Uma nota sobre comunidades tradicionais e unidades de conservação. Ruris, Campinas, v. 7, n. 2, set. $2013 . \quad$ Disponível em: em: $\quad<$ https://www.ifch.unicamp.br/ojs/index.php/ruris/article/download/1887/1366 >. Acesso em: 10 fev. 2019.

ALMEIDA, Paulo Guilherme de. Aspectos Jurídicos da Reforma Agrária no Brasil. São Paulo: LTr, 1990.

ANDERSON, Benedict. Nação e consciência nacional. São Paulo: Ática, 1989.

ANDRADE, Maristela de Paula. Terra de índio: identidade étnica e conflito em terras de uso comum. São Luís-MA: EDUSFAMA, 2008. (Coleção Humanidades, v. 3).

ARNAUD, André-Jean; ATIENZA, Manuel. Jurisdicidade. In: ARNAUD, André-Jean (Dir.). Dicionário enciclopédico de teoria e de sociologia do direito. Tradução de Patrice Charles, F. X. Willaume. Rio de Janeiro: Renovar, 1999. p. 433-437.

ASSEMBLEIA NACIONAL CONSTITUINTE. Entre a terra produtiva e a função social. Jornal da Constituinte, Brasília, v. 386, n. 46, 9 a 15 de maio de 1988. Disponível em: < https://www2.camara.leg.br/atividade-legislativa/legislacao/Constituicoes_Brasileiras/ constituicao-cidada/publicacoes/Jornal\%20da\%20Constituinte/n-\%2046\%20\%2009\%20a\%2015\%20maio\%201988.pdf > Acesso em: 1 mar. 2019.

ASSEMBLEIA NACIONAL CONSTITUINTE. As cidades devem servir ao social. Jornal da Constituinte, Brasília, v. 386, n. 46, 9 a 15 de maio de 1988. Disponível em: < https://www2.camara.leg.br/atividade-legislativa/legislacao/Constituicoes_Brasileiras/ constituicao-cidada/publicacoes/Jornal\%20da\%20Constituinte/n-\%2046\%20\%2009\%20a\%2015\%20maio\%201988.pdf > Acesso em: 1 mar. 2019.

ASSEMBLEIA GERAL DA ONU. Declaração das Nações Unidas sobre os direitos dos povos indígenas, treze de setembro, de 2007. Disponível em: < https://pib.socioambiental.org/files/file/PIB_institucional/DECLARACAO_DAS_NAC OES_UNIDAS_SOBRE_OS_DIREITOS_DOS_POVOS_INDiGENAS.pdf $>$. Acesso em: 12 jan. 2019.

ASSIER-ANDRIEU, Louis. L'anthropologie et la modernité du droit. Anthropologie et Sociétés, Quebec, v. 13, n. 1, p. 21-33, 1989. Disponível em: < https://www.erudit.org/ fr/revues/as/1989-v13-n1-as781/015053ar/ >. Acesso em: 6 fev. 2019.

O direito nas sociedades humanas. Tradução de Maria Ermantina Galvão. São Paulo: Livraria Martins Fontes, 2000. 
Penser le temps culturel du droit, L'Homme [En ligne], n. 160, p. 6790, oct./déc. 2001. Disponível em: < https://journals.openedition.org/lhomme/ pdf/125 >. Acesso em: 6 fev. 2019.

BAHIA (Estado) (1989). Constituição do Estado. Disponível em: < http://www.lex.com. br/legis_14128604_CONSTITUICAO_DO_ESTADO_DA_BAHIA.aspx >. Acesso em: 9 fev. 2019.

BARROS, Wellington Pacheco Barros. Curso de direito agrário. 7. ed. Porto Alegre: Livraria do Advogado, 2012.

BELLEY, Jean-Guy. Deux journées dans la vie du droit. Canadian Journal of Law and Society, Cambridge, v. 3, p. 27-52, 1988. Disponível em: < https://doi.org/10.1017/ $\underline{\mathrm{S} 0829320100001320}$ >. Acesso em: 6 fev. 2019.

Le pluralisme juridique comme orthodoxie de la science du droit. Canadian journal of law and society, Fredericton, Canada, v. 26, p. 257-276, 2011. Disponível em: $<\quad$ https://www.cambridge.org/core/journals/canadian-journal-of-law-and-society-larevue-canadienne-droit-et-societe/article/le-pluralisme-juridique-comme-orthodoxie-dela-science-du-droit/B067D5409FAC43E8636AD263D1A5979C >. Acesso em: 13 mar. 2019.

Le Droit comme terra incognita: Conquérir et construire le pluralisme juridique. Canadian Journal of Law and Society, Cambridge, v. 12, n. 2, p. 1-15, 1997. Disponível em: < https://doi.org/10.1017/S0829320100005329 >. Acesso em: 6 fev. 2019.

BERCOVICI, Gilberto. A Constituição de 1988 e a função social da propriedade". Revista de Direito Privado, São Paulo, v. 2, n. 7, jul./set. 2001, p. 69-84.

BERGAMASCO, Sonia Maria Pessoa Pereira; NORDER, Luis Antonio Cabello. O que são assentamentos rurais? São Paulo: Brasiliense, 1996.

BERGAMASCO, Sonia Maria Pessoa Pereira. A realidade dos assentamentos rurais por detrás dos números. Estudos Avançados, São Paulo, v. 11, n. 31, p. 37-49, dez. 1997. Disponível em: < http://www.scielo.br/scielo.php?script=sci_arttext\&pid=S0103$\underline{40141997000300003 \& \operatorname{lng}=\mathrm{en} \& \mathrm{nrm}=\mathrm{iso}}>$. Acesso em: 10 mar. 2019. (Electronic Document Format [APA]).

BERNARD, Picon. Du rural à l'environnement. La question de la nature aujourd'hui. In: Economies, sociétés, civilisations. Annales. Paris: Armand Colin, Année 46, n. 3, mai/juin 1991. pp. 615-617. Disponível em: < https://www.persee.fr/issue/ahess_03952649_1991_num_46_3? sectionId=ahess_0395-

2649_1991_num_46_3_278966_t1_0615_0000_002 >. Acesso em: 9 fev. 2019.

BEVILÁQUA, Clóvis. Direito das coisas. v. I. Brasília: Senado Federal, Conselho Editorial, 2003. 
BLANKENBURG, Erhard; CAPELLER, Wanda Maria de Lemos. Cultura jurídica. In: ARNAUD, André-Jean (Dir.). Dicionário enciclopédico de teoria e de sociologia do direito. Tradução de Patrice Charles, F. X. Willaume. 2. ed. Rio de Janeiro: Renovar, 1999. p. 197-200.

BORGES, Roxana Cardoso Brasileiro. Função ambiental da propriedade e reforma agrária. In: SIVEIRA, Domingos Sávio Dresch da; XAVIER, Flávio Sat Anna (org.). Direito Agrário em debate. Porto Alegre: Livraria do Advogado, 1998. p. 291311.

BOURDIEU, Pierre. Habitus, code et codification. Actes de la recherche en sciences sociales. Paris, v. 64, pp. 40-44, sept. 1986. [Communication présentée à Neuchâtel en mai 1983] Disponível em: < https://www.persee.fr/doc/arss_0335-5322_1986_num_64_ $\underline{1 \_2335}>$. Acesso em: 6 fev. 2019.

Brasil, 2001.

Meditações Pascalianas. Tradução de Sergio Miceli. Rio de Janeiro: Bertrand O poder simbólico. Tradução de Fernando Tomaz. Rio de Janeiro: Bertrand Brasil, 2012.

O senso prático. Tradução de Maria Ferreira. 3. ed. Petrópolis: Editora Vozes, 2013.

BRANDÃO, Carlos Rodrigues. A partilha da vida. São Paulo: Geic/cabral Editora, 1995.

BRASIL. Constituição Federal (1824). Disponível em: < http://www.planalto.gov.br/ ccivil_03/Constituicao/Constituicao24.htm >. Acesso em: 24 fev. 2019.

BRASIL. Lei $n$. 601, de 18 de setembro de 1850. Disponível em: < http://www.planalto.gov.br/ccivil_03/LEIS/L0601-1850.htm >. Acesso em: 24 fev. 2019.

BRASIL. Decreto n. 1.318, de 30 de janeiro de 1854. Disponível em: $<$ http://www2.camara.leg.br/legin/fed/decret/1824-1899/decreto-1318-30-janeiro-1854558514-publicacaooriginal-79850-pe.html >. Acesso em 24 fev. 2019.

BRASIL. Constituição Federal (1891). Disponível em: < http://www.planalto.gov.br/ccivil_03/Constituicao/Constituicao91.htm >. Acesso em: 4 fev. 2019.

BRASIL. Código Civil (1916). Instituído pela Lei n. 3.071, de $1^{\circ}$ de janeiro de 1916. Disponível em: < http://www.planalto.gov.br/ccivil_03/LEIS/L3071.htm > Acesso em: 3 fev. 2019.

BRASIL. Constituição Federal (1934). Disponível em: < https://www.planalto.gov.br/ ccivil_03/constituicao/constituicao34.htm >. Acesso em: 9 jan. 2019.

BRASIL. Constituição Federal (1937). Disponível em: < http://www.planalto.gov.br/ccivil_03/Constituicao/Constituicao37.htm >. Acesso em: 4 fev. 2019. 
BRASIL. Decreto-lei n. 2.848, de 7 de dezembro de 1940. Disponível em: < http://www.planalto.gov.br/ccivil_03/decreto-lei/Del2848compilado.htm >. Acesso em: 19 fev. 2019.

BRASIL. Constituição Federal (1946). Disponível em: < http://www.planalto.gov.br/ccivil_03/Constituicao/Constituicao46.htm >. Acesso em: 5 fev. 2019.

BRASIL. Lei $n$. 4.132, de 10 de setembro de 1962. Disponível em: < http://www.planalto.gov.br/ccivil_03/LEIS/L4132.htm >. Acesso em: 10 fev. 2019.

BRASIL. Lei Delegada n. 11, de 11 de outubro de 1962. Disponível em: < http://www2.camara.leg.br/legin/fed/leidel/1960-1969/leidelegada-11-11-outubro-1962364968-publicacaooriginal-1-pl.html >. Acesso em: 5 fev. 2019.

BRASIL. Emenda Constitucional n. 10, de 9 de novembro de 1964. Disponível em: < http://www2.camara.leg.br/legin/fed/emecon/1960-1969/emendaconstitucional-10-9novembro-1964-364969-publicacaooriginal-1-pl.html >. Acesso em 26 fev. 2019.

BRASIL. Lei $n$. 4.504, de 30 de novembro de 1964. Disponível em: < http://www.planalto.gov.br/ccivil_03/leis/L4504.htm >. Acesso em: 5 fev. 2019.

BRASIL. Decreto $n$. 59.456, de 4 de novembro de 1966. Disponível em: < http://www2.camara.leg.br/legin/fed/decret/1960-1969/decreto-59456-4-novembro1966-399970-publicacaooriginal-38471-pe.html >. Acesso em 13 mar. 2019.

BRASIL. Constituição Federal (1967). Disponível em: < http://www.planalto.gov.br/ccivil_03/Constituicao/Constituicao67.htm >. Acesso em: 5 fev. 2019.

BRASIL. Decreto-Lei n. 582, de 15 de maio de 1969. Disponível em: < http://www.planalto.gov.br/ccivil_03/decreto-lei/1965-1988/Del0582.htm >. Acesso em: 27 fev. 2019.

BRASIL. Emenda Constitucional n. 1, de 17 de outubro de 1969. Disponível em: < http://www.planalto.gov.br/ccivil_03/Constituicao/Emendas/Emc_anterior1988/emc01$\underline{69 . h t m}>$. Acesso em: 5 fev. 2019.

BRASIL. Decreto n. 1.110, de 9 de julho de 1970. Disponível em: < http://www.planalto.gov.br/ccivil_03/decreto-lei/1965-1988/Del1110.htm >. Acesso em: 1 mar. 2019.

BRASIL. Lei $n$. 6.938, de 31 de agosto de 1981. Disponível em: < http://www.planalto.gov.br/ccivil_03/Leis/L6938.htm >. Acesso em: 18 fev. 2019. 
BRASIL. Decreto $n$. 87.457, de 16 de agosto de 1982. Disponível em: < http://www.planalto.gov.br/CCIVIL_03/decreto/1980-1989/1980-1984/D87457.htm $>$. Acesso em: 1 mar. 2019.

BRASIL. Lei n. 7.231, de 23 de outubro de 1984. Disponível em: < http://www.planalto.gov.br/ccivil_03/LEIS/1980-1988/L7231.htm >. Acesso em: 4 mar. 2019.

BRASIL. Decreto $n$. 91.214, de 30 de abril de 1985. Disponível em: < http://www.planalto.gov.br/ccivil_03/decreto/1980-1989/1985-1987/D91214.htm >. Acesso em: 1 mar. 2019.

BRASIL. Decreto n. 91.450, de 18 de junho de 1985. Disponível em: < https://www2.camara.leg.br/legin/fed/decret/1980-1987/decreto-91450-18-julho-1985441585-publicacaooriginal-1-pe.html >. Acesso em: 1 mar 2019.

BRASIL. Senado. Mensagem n. 330, de 28 de junho de 1985. Disponível em: < https://www.senado.leg.br/publicacoes/anais/constituinte/emenda.pdf >. Acesso em: 1 mar 2019.

BRASIL. Decreto $n$. 91.766, de 10 de outubro de 1985. Disponível em : < https://www2.camara.leg.br/legin/fed/decret/1980-1987/decreto-91766-10-outubro1985-441738-norma-pe.html >. Acesso em: 9 mar. 2018.

BRASIL.Emenda Constitucional n. 26, de 27 de novembro de 1985. Disponível em: < https://www25.senado.leg.br/web/atividade/materias/-/materia/9185 $>$. Acesso em: 1 mar. 2019.

BRASIL. Decreto-lei n. 2.363, de 21 de outubro de 1987. Disponível em: < http://www.planalto.gov.br/ccivil_03/decreto-lei/1965-1988/Del2363.htm >. Acesso em: 1 mar. 2019.

BRASIL. Constituição Federal (1988). Disponível em: < http://www.planalto.gov.br/ ccivil_03/constituicao/constituicaocompilado.htm >. Acesso em: 9 fev. 2019.

BRASIL. Medida Provisória n. 29, de 15 de janeiro de 1989. Disponível em: < http://www.planalto.gov.br/Ccivil_03/MPV/1988-1989/029.htm >. Acesso em: 1 mar. 2019.

BRASIL. Decreto Legislativo n. 2, de 21 de outubro de 1989. Disponível em: < https://www2.camara.leg.br/legin/fed/decleg/1989/decretolegislativo-2-29-marco-1989360192-publicacaooriginal-1-pl.html >. Acesso em: 1 mar. 2019.

BRASIL. Lei n. 8.629, de 25 de fevereiro de 1993. Disponível em: < http://www.planalto.gov.br/ccivil_03/LEIS/L8629.htm >. Acesso em: 16 fev. 2019.

BRASIL. Decreto $n$. 2.250, de 11 de junho de 1997. Disponível em: < http://www.incra.gov.br/sites/default/files/uploads/legislacao/leis/indice_legislacao_21. 02.19.pdf >. Acesso em: 8 mar. 2019 
BRASIL. Medida Provisória n. 1.911-12, de 25 de novembro de 1999. Disponível em: < http://www.planalto.gov.br/ccivil_03/mpv/antigas/1911-12.htm >. Acesso em: 4 mar. 2019.

BRASIL. Medida Provisória n. 1.999-14, de 13 de janeiro de 2000. Disponível em: < https://www2.camara.leg.br/legin/fed/medpro/2000/medidaprovisoria-1999-14-13janeiro-2000-370151-norma-pe.html >. Acesso em: 13 mar. 2019.

BRASIL. Lei n. 9.985, de 18 de julho de 2000. Disponível em: < http://www.planalto.gov.br/ccivil_03/LEIS/L9985.htm >. Acesso em: 10 fev. 2019.

BRASIL. Lei n. 10.406, de 10 de janeiro de 2002. Disponível em: < http://www.planalto.gov.br/ccivil_03/LEIS/2002/L10406.htm >. Acesso em: 26 fev. 2019.

BRASIL. Lei $n$. 10.683, de 28 de maio de 2003. Disponível em: < http://www.planalto.gov.br/CCivil_03/leis/2003/L10.683.htm >. Acesso em: 13 mar. 2019.

BRASIL. Tribunal de Contas da União. Relatório de Levantamento de Auditoria. n. 005.888/2003-0. Acordão $n$. 557/2004. Plenário. Disponível em: < https://contas.tcu.gov.br/pesquisaJurisprudencia/\#/detalhamento/11/\%252a/NUMACOR DAO\%253A557\% 2520ANOACORDAO\%253A2004/DTRELEVANCIA\%2520desc\% 252C\%2520NUMACORDAOINT\%2520desc/false/1/false >. Acesso em: 5 mar. 2019.

BRASIL. Lei n. 11.326, de 24 de julho de 2006. Disponível em: < http://www.planalto.gov.br/ccivil_03/_Ato2004-2006/2006/Lei/L11326.htm >. Acesso em: 2 fev. 2019.

BRASIL. Lei $n$. 11.346, de 15 de setembro de 2006. Disponível em: < http://www.planalto.gov.br/ccivil_03/_Ato2004-2006/2006/Lei/L11346.htm >. Acesso em: 23 fev. 2019.

BRASIL. Lei n. 11.952, de 25 de junho de 2009. Disponível em: < http://www.planalto.gov.br/ccivil_03/_Ato2007-2010/2009/Lei/L11952.htm >. Acesso em: 2 mar. 2019.

BRASIL. Decreto $n$. 7.280, de 31 de agosto de 2010. Disponível em: < http://www2.camara.leg.br/legin/fed/decret/2010/decreto-7280-31-agosto-2010-608247publicacaooriginal-129290-pe.html >. Acesso em: 13 mar. 2019.

BRASIL. Decreto $n$. 7.255, de 4 de agosto de 2010. Disponível em: < http://www.planalto.gov.br/ccivil_03/_ato2007-2010/2010/decreto/D7255.htm >. Acesso em: 13 mar. 2019. 
BRASIL. Lei $n$. 13.123, de 20 de maio de 2015. Disponível em: < http://www.planalto.gov.br/ccivil_03/_Ato2015-2018/2015/Lei/L13123.htm >. Acesso em 14 mar. 2019.

BRASIL. Ministério do Desenvolvimento Agrário. Instituto Nacional de Colonização e Reforma Agrária. Instrução Normativa n. 83, de 30 de julho de 2015. Disponível em: < http://www.lex.com.br/legis_27012636_INSTRUCAO_NORMATIVA_N_83_DE_30_ DE_JULHO_DE_2015.aspx >. Acesso em 16 de fevereiro de 2019.

BRASIL. Proposta de Emenda à Constituição n. 7, de 2016. Disponível em: < https://legis.senado.leg.br/sdleg-getter/documento?dm=4675453\&ts $=1548960320888 \&$ disposition=inline $>$. Acesso em: 16 fev. 2019.

BRASIL. Proposta de Emenda à Constituição n. 258 de 2016. Disponível em: <https://www.camara.leg.br/proposicoesWeb/prop_mostrarintegra;jsessionid=0039DE6 6E233658AB380189B4FA29307.proposicoesWebExterno2?codteor=1677078\&filenam $\underline{\mathrm{e}=\mathrm{Avvulso}+\mathrm{PEC}+258 / 2016}$ >. Acesso em: $16 \mathrm{fev} .2019$.

BRASIL. Medida Provisória n. 726, de 12 de maio de 2016. Disponível em: < http://www.planalto.gov.br/ccivil_03/_Ato2015-2018/2016/Mpv/mpv726.htm >. Acesso em: 4 mar. 2019.

BRASIL. Decreto $n$. 8.780, de 27 de maio de 2016. Disponível em: < http://www.planalto.gov.br/ccivil_03/_Ato2015-2018/2016/Decreto/D8780.htm >. Acesso em: 4 mar. 2019

BRASIL. Decreto $n .8 .865$, de 29 de setembro de 2016. Disponível em: < http://www.planalto.gov.br/ccivil_03/_Ato2015-2018/2016/Decreto/D8865.htm\#art6 $>$. Acesso em: 4 mar. 2019.

BRASIL. Decreto $n$. 8.955, de 11 de janeiro de 2017. Disponível em : < http://www.planalto.gov.br/ccivil_03/_ato2015-2018/2017/decreto/D8955.htm >. Acesso em 13 mar. 2019.

BRASIL. Lei n. 13.465, de 11 de julho de 2017. Disponível em: < .http://www.planalto.gov.br/Ccivil_03/_Ato2015-2018/2017/Lei/L13465.htm\#art2 >. Acesso em: 13 mar. 2019.

BRASIL. Proposta de Emenda à Constituição n. 430 de 2018. Disponível em: < https://www.camara.leg.br/proposicoesWeb/prop_mostrarintegra;jsessionid=207C82C6 36A518DADEA05057CF67523E.proposicoesWebExterno2?codteor=1676138\&filena $\underline{\text { me}=A v u l s o+-P E C+430 / 2018}>$. Acesso em: 16 fev. 2019.

BRASIL. Decreto $n$. 9.282, de 7 de fevereiro de 2018. Disponível em: < http://legis.senado.leg.br/legislacao/DetalhaSigen.action?id=26353651 >. Acesso em: 2 mar. 2019.

BRASIL. Medida Provisória n. 870, de $1^{o}$ de janeiro de 2019. Disponível em: < http://www.in.gov.br/web/guest/materia/- 
/asset_publisher/Kujrw0TZC2Mb/content/id/57510830/do1esp-2019-01-01-medidaprovisoria-n-870-de-1-de-janeiro-de-2019-57510692 >. Acesso em: 2 mar. 2019.

BRASIL. Decreto $n$. 9.667, de 2 de janeiro de 2019. Disponível em: < http://www.planalto.gov.br/ccivil_03/_ato2019-2022/2019/decreto/D9667.htm >. Acesso em: 2 mar. 2019.

BRUNO, Regina. O Estatuto da Terra: entre a conciliação e o confronto. Estudos Sociedade e Agricultura, Rio de Janeiro, n. 5, p. 5-31, nov. 1995. Disponível em:

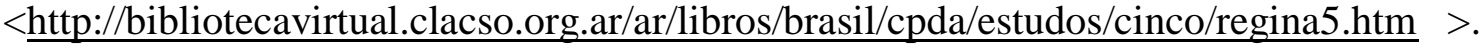
Acesso em: 26 fev. 2019.

BRUNO, Regina. José Gomes da Silva. Entrevista. Estudos Sociedade e Agricultura. v. 6. Rio de Janeiro: UFRJ, 1996. p. 37.

CARDOSO, Ciro Flamarion S. Cardoso. O trabalho na América Latina colonial. São Paulo: Editora ática, 1985.

CARVALHO, Horácio Martins de. Uma ressignificação para a reforma agrária no Brasil. Texto I - Teses. In: STÉDILE, João Pedro (org.). A questão agrária no Brasil. Debates sobre a situação e perspectivas da reforma agrária na década de 2000. São Paulo: Expressão Popular, 2013. p. 127-141.p. 130 e s.

CASA CIVIL. Programas da Secretaria especial de Agricultura Familiar $e$ desenvolvimento Agrário. Disponível em: < http://www.mda.gov.br/sitemda/secretaria/ saf/programas >. Acesso 2 de fev. 2019.

CASTEL, Robert; HAROCHE, Claudine. Propriété privée, propriété sociale, propriété de soi. Entretiens sur la construction de l'individu moderne. Paris: Fayard, 2001.

CASTRO, Eduardo Viveiros de; FERNANDES, Pádua. A indianidade é um projeto de futuro, não uma memória do passado: Entrevista com Eduardo Viveiros de Castro. São Paulo: Universidade Nove de Julho, 2011 (Entrevista). Prisma Jurídico, São Paulo, v. 10, n. 2, p. 257-268, jul./dez. 2011. Disponível em: < https://www.redalyc.org/html/ 934/93421623002/index.html >. Acesso em: 9 fev. 2019.

CHAUVIRÉ, Christiane; CHEVAllIER, Stéphane. Dictionnaire Bourdieu. Paris: Ellipses Édition, 2010.

CLASTRES, Pierre. Sociedade contra o Estado. Tradução de Theo Santiago. São Paulo: Cosac Naif, 2012.

COMISSÃO NACIONAL DA VERDADE. Relatório. Texto 5 - violação dos direitos humanos dos povos indígenas, p. 203-262, dez. 2014 (Publicação Online). Disponível em: < $\quad$ http://www.cnv.gov.br/images/pdf/relatorio/Volume\%202\%20\%20Texto\%205.pdf >. Acesso em: 20 fev. 2019. 
COMISSÃO NACIONAL DA VERDADE. Relatório. Texto 3 - violação dos direitos humanos dos camponeses, p. 91-153, dez. 2014 (Publicação Online). Disponível em: < http://www.cnv.gov.br/images/pdf/relatorio/Volume\%202\%20-\%20Texto\%203.pdf >. Acesso em: 20 fev. 2019.

COMISSÃO PASTORAL DA TERRA NACIONAL. [s.d.], (Publicação Online). Disponível em: < https://www.cptnacional.org.br/component/jdownloads/send/12trabalho-escravo/ 14089-trabalho-escravo-2017?Itemid=0 >. Acesso em: 19 fev. 2019.

COMMAILLE, Jacques. Normes juridiques et régulation sociale. Retour a la sociologie générale. In: CHAZEL, François; COMMAILLE, Jacques. (dir.). Une science sociale pour la pratique juridique ? Paris: LGDJ, 1992. Droit et Société, v. 20-21. p. 325-326, 1992. Disponível em: < https://www.persee.fr/doc/dreso_07693362_1992_num_20_1_1656_t1_0325_0000_4 >. Acesso em: 6 fev. 2019.

Hábito. In: ARNAUD, André-Jean (Dir.). Dicionário enciclopédico de teoria e de sociologia do direito. Tradução de Patrice Charles, F. X. Willaume. 2. ed. Rio de Janeiro: Renovar, 1999. p. 373-374.

COMMAILLE, Jacques. La judiciarisation. Une nouvelle économie de la légalité face au social et au politique ? Lille: CERAT, 2002 (Note de bilan d'étape du groupe « Judiciarisation de la société et du politique »). Disponível em: $<$ http://www.afsp.mshparis.fr/archives/congreslille/cong2002 crat18.pdf >. Acesso em: 10 fev. 2019.

. Uma Sociologia Política do Direito. Revista Da Faculdade De Direito USP, v. 108, p. 929-933, 2013. Disponível em: < http://www.revistas.usp.br/ rfdusp/article/view/68009 >. Acesso em: 10 fev. 2019.

À quoi nous sert le droit? Paris: Éditions Gallimard, 2015.

COMMAILLE, Jacques; DUMOULIN, Laurence; ROBERT, Cécile (dir.). La jurisdiction du politique. Paris: LGDJ, 2010.

COMPARATO, Fábio Konder. Direitos de deveres fundamentais em matéria de propriedade. In: STROZAKE, Juvelino José (org.). A questão agrária e a justiça. São Paulo: Editora Revista dos Tribunais, 2000, p. 130-147.

\section{CONFEDERAÇÃO NACIONAL DOS TRABALHADORES E TRABALHADORAS NA AGRICULTURA FAMILIAR. Disponível em: https://contrafbrasil.org.br/conteudo/quem-somos/ >. Acesso em: 2 fev. 2019}

COSTA, Emília Viotti da Costa. Da Monarquia à República: momentos decisivos. 9. ed. São Paulo: Editora UNESP, 2010.

CUNHA, Manuela Carneiro da; ALMEIDA, Mauro William Barbosa de. Populações Indígenas, Povos Tradicionais e Preservação na Amazônia. In: CAPOBIANCO, João Paulo Ribeiro (Coord.). Biodiversidade na Amazônia brasileira: avaliação e ações prioritárias para a conservação, uso sustentável e repartição de benefícios. São Paulo: Instituto Socioambiental. Estação Liberdade, 2001. p. 184-193. Disponível em: < 
https://www.bdpa.cnptia.embrapa.br/consulta/busca? $\mathrm{b}=\mathrm{ad} \&$ biblioteca=vazio\&busca $=\mathrm{au}$ toria:\%22CAPOBIANCO,\%20J.\%20P.\%20R.\%22 >. Acesso em: 9 fev. 2019.

DANOWSKI, Débora; CASTRO, Eduardo Viveiros de. Há mundo por vir? Ensaio sobre os medos e os fins. Florianópolis: Desterro, Cultura e Barbárie; Instituto Socioambiental, 2014.

DAVIS, Shelton H. Antropologia do direito: estudo comparativo de categorias de dívida e contrato. Tradução de Vera Maria Cândido Pereira. Rio de Janeiro: Zahar, 1973.

DESCOLA, Philippe. Outras naturezas, outras culturas. Tradução de Cecília Ciscato. São Paulo: Editora 34, 2016.

DIEGUES, Antônio Carlos Sant'Anna. O mito moderno da natureza intocada, 2. ed. São Paulo: Editora Hucitec, 1998.

DIEGUES, Antônio Carlos; ARRUDA, Rinaldo S. V. (org). Saberes tradicionais e biodiversidade no Brasil. Brasília: Ministério do Meio Ambiente. São Paulo: USP, 2001.

DIÉGUES JÚNIOR, Manuel. Reforma agrária. Revista de Filosofia Síntese. Rio de Janeiro, v. 1, n. 3, p. 14- 29, 1959. Disponível em: < http://faje.edu.br/periodicos/index.php/Sintese/article/view/3095 >. Acesso em: 3 mar. 2019.

DUMONT, Louis. Homo aequalis. Gènese et épanouissement de l'idéologie économique. Paris: Édtions Gallimard, 1977.

La genèse chrétienne de l'individualisme moderne. Une vue modifiée de nos origines. Dans Le Débat, Paris, n. 15, p. 124-146, 1981/8. Disponível em: < https://www.cairn.info/revue-le-debat-1981-8-page-124.htm >. Acesso em: 24 fev. 2019

Essais sur l'individualisme. Une perspective anthropologique sur l'idéologie moderne. Paris: Éditions du Seuil, 1983.

EBERHARD, Christoph. Para uma teoria jurídica intercultural: o desafio dialógico. Tradução de Roberto Cataloto Costa. Revista direito e democracia, Canoas, v. 3, n. 2, p. 489-530, jul./dez. 2002.

L'anthropologie du Droit : Un itinéraire entre altérité, complexité et interculturalité. In : Conférence donnée à l'Université Jules Verne de Picardie, Amiens, 24 mai 2002. Disponível em: < http://www.dhdi.free.fr/recherches/theoriedroit/articles/eberaltcomplinter.pdf $>$. Acesso em: 13 mar. 2019.

O direito no mundo globalizado: em direção à "boa governança" através do diálogo intercultural. Direito, Estado e Sociedade, Rio de Janeiro, n. 33, p. 6-18, jul./dez. 
2008. Disponível em: $<\quad$ https://revistades.jur.pucrio.br/index.php/revistades/article/download/235/212 >. Acesso em: 10 fev. 2019.

Au-delà de l'universalisme et du relativisme : L'horizon d'un pluralisme responsable. Anthropologie et Sociétés, Quebec, v. 33, n. 3, p. 79-100, 2009.

. L'impact méthodologique de l'analyse plurale dans l'étude anthropologique des cultures juridiques. In: OTIS, G. (dir.). Méthodologie du pluralisme juridique. Paris : Karthala Editions, 2012. p. 53-96, Disponível em: < http://www.dhdi.free.fr/recherches/theoriedroit/articles/EberhardPluralismeCulturesJuri diques.pdf >. Acesso em: 13 mar. 2019. (Coll. 4 vents)

. De l'autre côté... La juridicité, Revue interdisciplinaire d'études juridiques, Bruxelles, v. 70, p. 77-83, 2013. Disponível em : < https://www.cairn.info/revueinterdisciplinaire-d-etudesjuridiques-2013-1-page-77.htm >. Acesso em: 13 mar. 2019.

Savoirs, 2011.

Droits de l'homme et dialogue interculturel. Paris: Éditions Connaissances et

Oser le plurivers. Pour une globalisation interculturelle et responsable. Paris: Éditions Connaissances et Savoirs, 2013.

EBERHARD, Christoph; LE ROY, Étienne. Visions du monde, théorie des pouvoirs et représentations du droit. Fondements structuraux d'une anthropologie politique du juridique. In: CHRÉTIEN-VERNICOS, Geneviève; RUDE-ANTOINE, Edwige (org.). Anthropologies et Droits. Etats des savoirs et orientations contemporaines. Paris: Dalloz, 2009.

ERNOUT, Alfred ; MEILLET, Alfred. Signum. In: ERNOUT, Alfred; MEILLET, Antoine. Dictionnaire étymologique de la langue latine: Histoire des mots. 4. ed. Corrections nouvelles par Jacques André, Paris: Klincksieck, 1985. p. 626-627

FACHIN, Edson. A função social da propriedade contemporânea (uma perspectiva da usucapião imobiliária rural). Porto Alegre: Sérgio Fabris Editor, 1988.

FACHIN, Luiz Edson. O estatuto da terra no Brasil: trinta anos ou cinco séculos?. Revista da Associação Brasileira de Reforma Agrária, São Paulo, v. 25, n.1, p. 127-135, 1995. Disponível em: < http://docvirt.com/docreader.net/DocReader.aspx?bib=hemerolt\& pagfis $=12612>$. Acesso em: 26 fev. 2019.

FERNANDES, Bernardo Mançano. Agricultura familiar e agricultura camponesa. In: XIII Encontro Nacional de Geógrafos. João Pessoa: Associação dos Geógrafos Brasileiros, 2002. CD-ROM.

FIDELES, Júnior Divino. A justa indenização na desapropriação agrária: como se formam as superindenizações. Rio de Janeiro: Lumem Juris, 2016.

(coord.). Lei n. 8.629/1993 comentada por Procuradores Federais. 2. ed.

Brasília: $\quad 2018 . \quad$ Disponível em:


http://www.incra.gov.br/sites/default/files/uploads/publicacoes/lei_8629-1993_-

comentada_por_procuradores_federais_2o_ed.___web.pdf >. Acesso em: 17 fev. 2019.

FIGUEIREDO, Guilherme José Purvim. A propriedade no direito ambiental. 3. ed. São Paulo: Editora Revista dos Tribunais, 2008.

FORNEL, Michel de. Habitus e etnométodos. In: LAGRAVE, RoseMarie; ENCREVÉ, Pierre (org.). Trabalhar com Bourdieu. Rio de Janeiro: Bertrand Brasil, 2005.

FRANÇA. Déclaration des Droits de l'Homme et du Citoyen, 26 août 1789. Disponível em: < https://www.legifrance.gouv.fr/Droit-francais/Constitution/Declaration-desDroits-de-1-Homme-et-du-Citoyen-de-1789 > . Acesso em: 24 fev. 2019.

FRANÇA. Code Civil des français, de 21 mars 1804. Disponível em: < http://data.legilux.public.lu/file/eli-etat-leg-memorial-1804-5-fr-pdf.pdf >. Acesso em: 3 fev. 2019.

GAFFIOT, Félix. Dictionnaire latin-français. Paris: Hachette, 1934.

GEERTZ, Clifford. A interpretação das culturas. Rio de Janeiro: Gen Grupo Editorial Nacional, 2011.

O saber local. Novos ensaios em antropologia interpretativa. Tradução de Vera Joscelyne. Rio de Janeiro: Editora Vozes, 2014.

GILBERT, Jérémie. Direito à terra como direito humano: argumentos em prol de um direito específico. SUR. Revista Internacional de Direitos Humanos / Sur - Rede Universitária de Direitos Humanos - v.1, n.1, jan.2004 - São Paulo, 2004, p. 121- 144.

GODELIER, Maurice. Racionalidade e irracionalidade na economia. Tradução de Maura R. Sardinha. Rio de Janeiro: Edições Tempo Brasileiro, [196-].

. L'idéel et le matériel. Paris: Fayard, 1984.

70, 1996.

O enigma da dádiva. Tradução de Pedro Miguel Elói Duarte. Lisboa: Edições

GODOY, Luciano de Souza. Direito Agrário Constitucional: o regime da propriedade. $2^{a}$ ed. São Paulo: Editora Atlas, 1999.

GODOI, Emília Pietrafesa de. Territorialidade: trajetórias e usos do conceito. Raízes (UFCG), Campina Grande, v. 34, n. 2, p. 8-17, jul./dez. 2014 (Conferência proferida na abertura do I Seminário do Laboratório de Estudos sobre Tradições [LETRA], na Universidade Federal de Campina Grande, 3 jun. 2014). Disponível em: < http://revistas.ufcg.edu.br/raizes/artigos/Artigo_339.pdf >. Acesso em: 9 fev. 2019. 
GOMES, Orlando. "A Função Social da Propriedade" In: Boletim da Faculdade de Direito: Estudos em Homenagem ao Prof. Dr. A. Ferrer-Correia. Coimbra: Universidade de Coimbra, 1989, p. 423-437.

. Direito reais. 10. ed. Rio de Janeiro: Editora Forense, 1994.

Fontes, 2003.

Raízes históricas e sociológicas do código civil brasileiro. São Paulo: Martins

GRINBERG, Keila. Código civil e cidadania. 3. ed. Rio de Janeiro: Jorge Zahar Editor, 2008.

GROSSI, Paolo. História da propriedade e outros ensaios. Tradução de Luiz Ermani Fritoli e Ricardo Marcelo Fonseca. Rio de Janeiro: Renovar, 2006.

GUIBET-LAFAYE. Caroline. La naturalisation de l'appropriation privative. Revue de philosophie économique, v. 14, p. 35-68, 2014/2. Disponível em: < https://www.cairn.info/revue-de-philosophie-economique-2014-2-page-35.htm $>$. Acesso em 13 mar. 2019.

GUIMARÃES, Alberto Passos; MEDEIROS, Leonilde Servolo. Reforma agrária. In: FGV CPDOC. Verbete, [s.d.], (Publicação Online). Disponível em: < http://www.fgv.br/cpdoc/acervo/dicionarios/verbete-tematico/reforma-agraria-5 >. Acesso em: 25 fev. 2019.

HERRERA, Carlo Miguel. Culture Juridique et Politique: Une Introduction. International Journal for the Semiotics of Law - Revue internationale de Sémiotique juridique, Dordrecht, v. 29, n. 4, p. 721-727, déc. 2016. Disponivel em: < https://link.springer.com/article/10.1007/s11196-016-9475-8 >. Acesso em: 6 fev. 2019.

HOBSBAWN, Eric. A era dos impérios - 1875-1914. [s.1.] PDL - Projeto Democratização da Leitura, [s.d.], (Publicação online).

HOLSTON, James. Cidadania insurgente: disjunções da democracia e da modernidade no Brasil. Tradução de Cláudio Carina. São Paulo: Companhia das Letras, 2013.

INCRA. Portaria n. 627, de 30 de julho de 1987. Disponível em: < http://www.incra.gov.br/sites/default/files/uploads/institucionall/legislacao-/portarias/portarias-de-1987/portaria_incra_p627_300787.pdf >. Acesso em: 9 mar. 2019.

INCRA. Portaria $n$. 477, de 6 de outubro de 1999. Disponível em: < http://www.incra.gov.br/sites/default/files/uploads/institucionall/legislacao-/portarias/portarias-de-1999/portaria_incra_p477_041199.pdf >. Acesso em: 10 mar. 2019.

INCRA. Portaria n. 1.141 de 19 de dezembro de 2003. Disponível em : < https://www.diariodasleis.com.br/legislacao/federal/416-cria-a-modalidade-de-projetode-assentamento-florestal-paf-destinada-a-ureas-com-aptiduo-para-a-produuuo- 
florestal-familiar-comunituria-e-sustentuvel-especialmente-aplicuvel-u-regiuo-norte-eesta.html >. Acesso em: 9 mar. 2019.

INCRA. Norma de Execução n. 9, de 6 de abril de 2001. Disponível em: < http://www.incra.gov.br/sites/default/files/uploads/legislacao/norma-execucao/ne_092001_proc_consolidacao_pa.pdf $>$. Acesso em: 9 mar. 2019.

INCRA. Norma de Execução n. 69, de 12 de março de 2008. Disponível em: < http://www.incra.gov.br/sites/default/files/uploads/legislacao/norma-execucao/ne_69$2008 \_$proc_criacao_e reconh_pas.pdf $>$. Acesso em: 9 mar. 2019.

INCRA. Manual de procedimentos para a criação, reconhecimento e aprovação de projetos de reforma agrária e unidades de conservação de uso sustentável - MDA. [s.1.], 2008.

INCRA. Portaria n. 338, de 9 de março de 2018. Disponível em: < http://www.in.gov.br/materia/-/asset_publisher/Kujrw0TZC2Mb/content/id/6261504/ do1-2018-03-13-portaria-n-338-de-9-de-marco-de-2018-6261500 >. Acesso em: 3 mar. 2019.

INCRA. Procuradoria Geral Especializada. Índice de Legislação Agrária. Brasília: INCRA, 2018. Disponível em: http://www.incra.gov.br/sites/default/files/uploads/legislacao/leis/indice_legislacao_21. 02.19.pdf >. Acesso em: 10 mar. 2019.

INCRA. Assentamentos. [s.d.]. Disponível em: < http://www.incra.gov.br/assentamento z. Acesso em: 9 mar. 2019.

INCRA. Incra nos Estados. Informações gerais sobre os assentamentos da Reforma Agrária, [s.d.], (Publicação Online). Disponível em: < http://painel.incra.gov.br/sistemas/index.php >. Acesso em: 13 mar. 2019.

INCRA. II Plano Nacional de Reforma Agrária, (Publicação Online). Disponível em: < http://www.incra.gov.br/media/servicos/publicacao/pnra/II_PNRA.pdf >. Acesso em: 9 mar. 2019.

JUNQUEIRA, Eduardo. Código Civil de 1916, [s.d.], (Publicação Online). Disponível em: $\quad<\quad$ http://cpdoc.fgv.br/sites/default/files/verbetes/primeirarepublica/C\%C3\%93DIGO\%20 CIVIL\%20DE\%201916.pdf >. Acesso em: 26 fev. 2019.

LAPLANTINE, François. Aprender Antropologia. Tradução de Marie-Agnès Chauvel. São Paulo: Brasiliense, 2006.

LARANJEIRA, Raymundo. Colonização e reforma agrária no Brasil. Rio de Janeiro: Editora Civilização Brasileira, 1983. 
LARRAÍN, Jorge. La Identidad Latinoamericana. Teoria e História. Estúdios Públicos. Santiago de Chile, n. 55, 1994. Disponível em: < https://www.insumisos.com/ lecturasinsumisas/Identidad\% 20latinoamericana.pdf >. Acesso em: 9 fev. 2019. p. 34.

LAVAL, Christian. L'homme économique. Essai sur les racines du néoliberalisme. Paris: Èditions Gallimard, 2007.

L'ESTOILE, Benoit de; SIGAUD, Lygia (orgs.). Ocupações de terra e transformações sociais. Rio de Janeiro: Editora FGV, 2006.

LE ROY, Étienne. Folklore juridique et Folk Law: Déplacements et enjeux d'une recherche internationale sur le " Droit des gens", Études rurales, Paris, n. 103/104, p. 139150, jul./dec. 1986. Disponível em: < http://www.jstor.org/stable/20125016 >. Acesso em: 13 mar. 2019.

Juristique et anthropologie: Un pari sur l'avenir. Journal of legal pluralism and unofficial law, London, n. 29, p 5-21, 1990. Disponível em: < https://heinonline.org/HOL/LandingPage?handle=hein.journals/jlpul29\&div=7\&id=\&pa ge >. Acesso em: 6 fev. 2019.

L'ordre négocié. A propos d'un concept en émergence In: paru dans Gérard, Philippe; OST, François; KERCHOVE, Michel Van de (éd.). Droit négocié, Droit imposé ?, Bruxelles: Publication des Facultés Universitaires Saint Louis, 1996, p 341351.

Le jeu des lois. Une anthropologie "dynamique” du Droit. Paris: LGDJ Lextenso, 1999 (Collection Droit et Société. Série anthropologique. v. 44).

Norma (em Antropologia do direito). In: ARNAUD, André-Jean (Dir.). Dicionário enciclopédico de teoria e de sociologia do direito. Tradução de Patrice Charles, F. X. Willaume. 2. ed. Rio de Janeiro: Renovar, 1999. p. 524-528.

Pluralisme et Universalisme juridiques propos d'étape d'un anthropologue du droit. L'étranger en France face au droit de la famille. Paris: La documentation française, 2000. Disponível em: < http://www.dhdi.free.fr/recherches/theoriedroit/articles/leroyplur.htm >. Acesso em: 13 mar. 2019.

L'hypothèse du multijuridisme dans un contexte de sortie de modernité. In: LAJOIE, André; MACDONALD, Roderick A.; JANDA Richard; ROCHER Guy (ed.), Théories et émergence du droit: pluralisme, surdétermination et effectivité, Bruxelles: Bruylant/Thémis, 2002. p. 29-43.

Marchés de droits et marché du Droit. Revue Tiers Monde. Paris, Tome 45, n. 177, p. 163-178, janv./mars 2004. Disponível em: < https://www.persee.fr/doc/ tiers_1293-8882_2004_num_45_177_5454 >. Acesso em: 6 févr. 2019.

Bricolages anthropologiques pour promouvoir, en Afrique et ailleurs, un dialogue entre univers juridiques, Revue de droit de McGill. Montreal, Canadá, v. 50, n. 
4, p. 951-966, 2005. Disponível em: < http://lawjournal.mcgill.ca/userfiles/other/6150631225245815_Le_Roy.pdf $>$. Acesso em 13 mar. 2019.

. Le trípode juridique. Variations anthropologiques sur um thème de flexible droit. L'Année Sociologique. Paris, v. 57, p. 341-351, 2. sem. 2007. p. 347. Disponível em: < https://www.jstor.org/stable/27890534?read-now=1\&seq=2\#page_ scan_tab_contents $>$. Acesso em: 9 fev. 2019.

. Autonomie du droit, hétéronomie de la juridicité. In: SACCO, Rodolfo (dir.). Le nuove ambizioni del sapere del giurista : anthropologica giuridica e traducttologia giuridica. Roma: Academia Nazionale dei Lincei, 2009, p. 99-133.

. Violence de la fonction symbolique et institutionnalisation du droit, contribution à une anthropologie de la juridicité et du pluralisme normatif. In: INHENTVEEN, Katharina; KLUTE, Georg. Begegnungen und Auseinandersetzungen Festschrift für Trutz von Trotha. Köln: Rüdiger Köppe Verlag, 2009. p. 12-30.

La terre de l'autre. Une anthropologie des régimes d'appropriation foncière. Paris: LGDJ, 2011.

La révolution de la juridicité, une réponse aux mondialisations. In: II Encontro Nacional de Antropologia do Direito, Universidade de São Paulo, 31 ago. 2011. (Paper referente à conferência de abertura do II ENADIR).

Les fondements de la socialisation juridique, entre droit et juridicité. In: Laboratoire d'Anthropologie Juridique de Paris. Pratiques citoyennes de droit. Cahiers d'anthropologie du droit 2010. Paris: Karthala, 2011, p. 169-192.

LE ROY, Étienne. The Agon and the Anthropology of Law. Une introduction à une relecture "dynamique" du conflit. In: Workshop "Conflict and antagonism in Nietzsche and beyond". Leiden, Mar. 2013. Disponível em: < www.thinkingafrica.org/V2/wp.../04/ Leiden-ELR-2013_3.docx >. Acesso em: 4 fev. 2019.

Quelques propositions pour une problématique partageable à Turin. In: LE ROY, Étienne. La terre et l'homme. Spaces er ressources convoités, entre le local et le global. Paris: Éditions Karthala, 2013.

Pourquoi, en Afrique, "le droit" refuse-t-il toujours le pluralisme que le communautarisme induit? Anthropologie et Sociétés, Quebec, v. 40, n. 2, p. 25-42, 2016. Disponível em: < https://www.erudit.org/fr/revues/as/2016-v40-n2-as02669/10375 10ar/ >. Acesso em: 6 fev. 2019.

Le mystère du droit foncier. Sens et non-sens d'une politique volontariste de généralisation de la propriété privée de la terre dans le décollage des économies des sociétés du " Sud". In: EBERHARD, Christoph (dir.). Enjeux fonciers et 
environnementaux. Dialogues afro-indiens. Pondichery: Institut Français de Pondichéry, 2017, p. 57-88 (Collection Sciences Sociales, n. 13).

LEÃO, Marília (org.). O direito humano à alimentação adequada e o sistema nacional de segurança alimentar e nutricional. Brasília: ABRANDH, 2013. Disponível em: < http://www.mds.gov.br/webarquivos/publicacao/seguranca_alimentar/DHAA_SAN.pdf >. Acesso em: 23 fev. 2019.

LEVI-STRAUSS. Antropologia estrutural. Tradução de Chaim Samuel Katz e Eginardo Pires. Rio de Janeiro: Tempo Brasileiro, 1975.

Antropologia estrutural dois. Tradução de Maria do Carmo Pandolfo. Rio de Janeiro: Tempo Brasileiro, 1993.

LIMA, Ruy Cirne. Pequena história territorial do Brasil: sesmarias e terras devolutas. 4. ed. São Paulo: Secretaria de Estado de Cultura, 1990.

LOCKE, John. Segundo tratado do governo civil. Tradução: Magda Lopes e Marisa Lobo da Costa. Petrópolis-RJ: Editora Vozes. Distribuição: Clube do Livro Liberal, [s.d.], (Publicação online). Disponibilizado em: < http://www.xr.pro.br/if/lockesegundo_tratado_sobre_o_governo.pdf >. Acesso em: 24 fev. 2019.

LOPES, Antonio Wagner Pereira et al. Práticas e Estratégias em Diferentes modalidades de Assentamento Rural. Retratos de Assentamentos, v. 17, n. 2, p. 171-196, jul. 2014. Disponível em: < http://retratosdeassentamentos.com/index.php/retratos/article/view/ 170/155>. Acesso em: 11 mar. 2019.

MACDONALD, Roderick A. L'hypothèse du pluralisme juridique dans les sociétés démocratiques avancées. Revue de droit de l'Université de Sherbrooke. Sherbrooke, v. 33, p. 133-152, 2002-2003. Disponível em: < https://www.usherbrooke.ca/droit/ fileadmin/sites/droit/documents/RDUS/volume 33/33-12-macdonald.pdf >. Acesso em: 6 fev. 2019.

MADJARIAN, Grégoire. L'invention de la propriété. De la terre sacrée à la société marchande. Paris: Editions L'Harmattan, 1991.

MARANHÃO (Estado) (1989). Constituição do Estado. Disponível em: < https://www2.senado.leg.br/bdsf/bitstream/handle/id/70443/CE_MA_EC_66.pdf? sequence $=15>$. Acesso em 9 fev. 2019.

MARCOS, Valéria. Da Luta Para Entrar Na Terra À Luta Para Permanecer Na Terra: A Realidade dos Assentamentos Rurais Paraibanos. Caderno do Nera, Presidente PrudenteSP, n.2, p. 51-73, 1998 (Série Estudos).

Solidariedade que tece redes: as estratégias de reprodução e recriação camponesa nos assentamentos do alto sertão paraibano. In: XIV Encontro Nacional de Geógrafos, 2006, Rio Branco. Anais do XIV Encontro Nacional de Geógrafos: Comunicação Coordenada. Rio Branco: AGB, 2006. p. 1-12. 
MARÉS, Carlos Frederico. A função social da terra. Porto Alegre: Sérgio Antonio Fabris Editor, 2003.

. Desapropriação sanção por descumprimento da função social?, Revista de Direito Agrário, Brasília: MDA|Incra|Nead|ABDA, ano 19, n. 18, 2006, p. 65-76.

MARÉS, Carlos Frederico; SAUER, Sérgio (coord.). Casos emblemáticos e experiências de mediação. Análise para uma cultura institucional de soluções alternativas de conflitos fundiários rurais. Brasília. Ministério da Justiça, Secretaria de Reforma do Judiciário, 2013. Disponível em: < https://terradedireitos.org.br/wp-content/uploads/2014/02/ Pesquisa-Conflitos-Fundi\%C3\%A1rios-Agr\%C3\%A1rios-Terra-de-Direitos.pdf >. Acesso em 13 mar. 2019.

MARTINS, José de Souza. A reforma agrária e os limites da democracia na "nova República”. São Paulo: Editora Hucitec, 1986.

Hucitec, 1991.

Expropriação e violência: a questão politica no campo. 3. ed. São Paulo: Os camponeses e a política no Brasil. 5. ed. Petrópolis: Editora Vozes, 1995.

- Reforma agrária: o impossível diálogo sobre a História possível. Tempo Social, São Paulo, v. 11, n. 2, p. 97-128, out. 1999 . Disponível em: < http://www.scielo.br/scielo.php?script=sci_arttext\&pid=S0103 >. Acesso em: 13 mar. 2019.

O futuro da Sociologia Rural e sua contribuição para a qualidade de vida rural. Estudos Avançados. São Paulo, v. 15, n. 43, p. 31-36, 2001. Disponível em: < http://www.revistas.usp.br/eav/issue/view/732 >. Acesso em: 10 fev. 2019.

MATHIEU, Nicole. "Rural et urbain unité et diversité dans les évolutions des modes d'habiter". In EIZNER, Nicole; JOLLIVET, Marcel (dir.), L'Europe et ses campagnes. Paris: Presses de Sc. Po, 1996. p. 187-215. Disponível em: < https://www.researchgate.net/profile/Mathieu_Nicole/publication/2995488 12_Ruralurbain_unite_et_diversite_des_modes_d\%27habiter_en_Europe/links/56fe981d08aea6b 77468cccf/Rural-urbain-unite-et-diversite-des-modes-dhabiter-en-Europe.pdf?origin= publication_detail >. Acesso em: 9 fev. 2019.

MAUSS, Marcel. Sociologia e antropologia. Tradução de Paulo Neves. São Paulo: CosacNaif, 2003.

MAZOYER, Marcel; ROUDAT, Laurence. História das agriculturas no mundo. Do Neolítico à crise contemporânea. Tradução de Cláudia F. Falluh Balduino Ferreira. São Paulo: Editora UNESP; Brasília: NEAD, 2010.

MEDEIROS, Leonilde Servolo de et al. (org.). Assentamentos rurais: uma visão multidisciplinar. São Paulo: UNESP, 1994. 
MEDEIROS, Leonilde Servolo de; BORGES, Tomas Pompeu Acioli. Estatuto da Terra (verbete). Rio de Janeiro: Editora da Fundação Getúlio Vargas, 2001. Disponível em: < http://www.fgv.br/cpdoc/acervo/dicionarios/verbete-tematico/estatuto-da-terra-1 $>$. Acesso em: 5 fev. 2019.

MEDEIROS, Leonilde Servolo de. Reforma agrária no Brasil. São Paulo: Fundação Perseu Abramo, 2003.

MEDEIROS, Leonilde Servolo de et al. (coord). Impactos dos assentamentos: um estudo sobre o meio rural brasileiro. Brasília: Instituto Interamericano de Cooperação para Agricultura - IICA, Núcleo de Estudos Agrários e Desenvolvimento Rural - NEAD. São Paulo: Unesp, 2004.

MEDEIROS, Leonilde Servolo de. LEITE, Sérgio (org.). Assentamentos rurais: mudança social e dinâmica regional. Rio de Janeiro: Mauad, 2004.

A formação dos assentamentos rurais no Brasil. Processos sociais e políticas públicas, Porto Alegre: Editora da Universidade Federal do Rio Grande do Sul, 2009;

MELO, Herena Neves Maués Corrêa de. A Ineficácia da Emenda Constitucional $n^{\circ}$ 81/2014 e a Desconstrução dos Fundamentos do Trabalho Escravo Contemporâneo In: INSTITUTO NACIONAL DE COLONIZAÇÃO E REFORMA AGRÁRIA (Incra). 30 anos da Constituição Federal de 1988. Revista de Direito Agrário. Brasília, ano 21, n. 22 , p. 215-234, 1973. (Edição Especial). Disponível em: < http://www.incra.gov.br/sites/default/files/uploads/publicacoes/revista_de_direito agrario_-no_22_-_ed._especial_30_anos_da_cf_de_1988_-_web.pdf $>$. Acesso em 19 de fevereiro de 2019. p. 218.

MEMÓRIA CHILENA. Biblioteca Nacional de Chile, [s.d.] (Publicação Online). Disponível em: < http://www.memoriachilena.cl/archivos2/pdfs/MC0016012.pdf >. Acesso em: 14 mar. 2019.

MENDES DE MIRANDA, Ana Paula. Antropologia, Estado Moderno e Poder: perspectivas e desafios de um campo em construção Avá. Revista de Antropología da Universidad Nacional de Misiones, Misiones, Argentina, n. 7, 2005, pp. 1-27,

MOCKLE, Daniel. Deux variations sur le thème des normes. Les Cahiers de droit, Quebec, v. 38, n. 2, p. 437-459, 1997. Disponível em: < https://www.erudit.org/fr/revues/ cd1/1997-v38-n2-cd3811/043446ar/ >. Acesso em: 6 fev. 2019.

MORGAN, Lewis Henry. A sociedade antiga ou investigações sobre as linhas do progresso humano desde a selvageria, através da barbárie, até a civilização. In: CASTRO, Celso (org). Evolucionismo cultural. Textos de Morgan, Tylor e Frazer. Tradução de Maria Lúcia de Oliveira. 2. ed. Rio de Janeiro: Zahar, 1877.

MOTA, Maria Sarita. Sesmarias e propriedade titulada da terra: o individualismo agrário na América Portuguesa. Saeculum - Revista de História, João Pessoa, n. 26, p. 29-45, jan./jun. 2012. Disponível em: < https://repositorio.iscte-iul.pt/bitstream/10071/14131/1/ Sesmarias\%20e\%20propriedade\%20titulada\%20da\%20terra.pdf $>$. Acesso em: 24 fev. 2019. 
MOTTA, Márcia Maria Menendes. Sesmeiros e Posseiros nas Malhas da Lei (um Estudo sobre os Debates Parlamentares acerca do Projeto de Lei de Terras - 1843/1850) In: LEITE, Sérgio Pereira; DUQUE, Ghislaine. Instituições e Políticas Públicas, Raízes, Campina Grande-PB, ano XVII, n. 18, set. 1998 [Edição especial temática, dedicada ao XVIII ENCONTRO NACIONAL DA APIPSA, realizado em Campina Grande-PB, entre 25 e 29 de novembro de 1996].

. Nas Fronteiras do Poder: Conflito e Direito à Terra no Brasil no Século XIX. $2^{a}$ edição. Niterói: Editora da Universidade Federal Fluminense, 2008.

MOTTA, Márcia Maria Menendes; GUIMARÃES, Elione. Propriedades e Disputas: Fontes para a História do Oitocentos. Guarapuava: Unicentro, 2011.

MOURA, Margarida Maria. Os herdeiros da terra: parentesco e herança numa área rural. São Paulo: Editora Hucitec, 1976. 97, 1982.

Invasão, expulsão e sucessão. Anuário Antropológico, São Paulo, v. 82, p. 82-

Margarida Maria. Camponeses. São Paulo: Ática. 1986.

Os deserdados da terra; a lógica costumeira e judicial dos processos de expulsão e invasão camponesa no sertão de Minas Gerais. Rio de Janeiro: Editora Bertrand Brasil S.A, 1988.

Dez livros para conhecer o Brasil rural. Desenvolvimento de material didático ou instrucional. São Paulo: Guia Bibliográfico da FFLCH, 2016. Disponível em: < https://www.fflch.usp.br/sites/fflch.usp.br/files/2017-11/Brasilrural.pdf >. Acesso em: 10 fev. 2019.

NEVES, Delma Pessanha. Reforma Agrária: idealizações, irrealizações e plausibilidades, Revista da Abra [s.1.], v. 25, n. 1, p 185-204, jan/abr. 1995. Disponível em: 〈 http://docvirt.com/docreader.net/DocReader.aspx?bib=hemerolt\&pagfis=12366 $>$. Acesso em: 13 mar. 2019.

Assentamento rural: confluência de formas de inserção social. Estudos Sociedade e Agricultura, [s.1.]. n. 13, p. 5-28, out. 1999. Disponível em: < http://bibliotecavirtual.clacso.org.ar/ar/libros/brasil/cpda/estudos/treze/delma13.htm >. Acesso em: 13 mar. 2019.

Assentamento e assentado: diversidades contextuais do processo de construção social. Retratos de Assentamentos, [s.1.], v. 19, n. 2, p. 215-244, jul. 2016. Disponível em: $<$ http://retratosdeassentamentos.com/index.php/retratos/article/view/244 >. Acesso em: 11 mar. 2019. 
NICOLAU, Gilda. Polissemia e pluralismo jurídico, o exemplo da propriedade. In: III Encontro Nacional de Antropologia do Direito, Universidade de São Paulo, 28 ago. 2013. (Conferência de abertura do III ENADIR).

NOBRE JUNIOR, Edilson Pereira. Desapropriação para Fins da Reforma Agrária. $3^{\mathrm{a}}$ edição. Curitiba: Juruá Editora, 2012.

NYAMDING, Ch. Pascal Messanga. Le Sacre et les conceptions du poivoir et du droi. Aux origines d'une lecture des archetypes. In: Laboratoire d'anthropologie Juridique de Paris. Quelques jalons d'une anthropologie du droit. Bulletin de liaison. Paris, n. 23, p. 13-17, juil. 1998. Disponível em: < http://www.dhdi.free.fr/ recherches/bulletins/ bull23.pdf $>$. Acesso em: 6 fev. 2019.

OLIVEIRA, Ariovaldo Umbelino de. A geografia das lutas no campo. 6. ed. São Paulo: Contexto, 1994.

Modo capitalista de produção, agricultura e reforma agrária. São Paulo: FFLCH/Labur Edições, 2007.

Reforma agrária. In: MOTA, Márcia (org.). Dicionário da terra. 2. ed. Rio de Janeiro: Editora Civilização Brasileira, 2010. p. 385- 391.

O campo brasileiro no final dos anos 1980. In: STEDILE, João Pedro (org). A questão agrária no Brasil. O debate na década de 1990. 2. ed. São Paulo: Editora Expressão Popular. 2013, p. 55-80.

OLIVEIRA, Ariovaldo Umbelino; FARIAS, Camila Salles de. O processo de constituição da propriedade privada da terra no Brasil. In: $12^{\circ}$ Encuentro de Geógrafos de América Latina, 2009, Montevidéo. Caminando en una América Latina en Transformación. Montevidéo: Universidad de La República, 2009. v. 1. p. 01-15.

ORGANIZAÇÃO DAS NAÇÕES UNIDAS. Food and Agriculture Organization of the United Nations [s.d.] (Publicação Online). Disponível em: < http://www.fao.org/landwater/land/fr/ >. Acesso em: 16 fev. 2019.

ORGANIZAÇÃO INTERNACIONAL DO TRABALHO (OIT). Convenção $n$. 169. Convenção sobre povos indígenas e tribais [s.d.] (Publicação Online). Disponível em: < http://www.planalto.gov.br/ccivil_03/_ato2004-2006/2004/decreto/d5051.htm >. Acesso em: 12 jan. 2019.

PALMEIRA, Moacir Gracindo Soares. Modernização, Estado e Questão Agraria. Estudos Avancados USP, São Paulo, v. 3, n.7, p. 87-108, 1989. Disponível em: < http://www.scielo.br/scielo.php?script=sci_arttext\&pid=S0103-40141989000300006 $>$. Acesso em: 26 fev. 2019.

Burocracia, política e reforma agrária. In: MEDEIROS, Leonilde et al. Assentamentos rurais: uma visão multidisciplinar. São Paulo UNESP, 1994, p. 49-68.

PANIKKAR, Raimon. Alternatives à la culture moderne. lnterculture, Montreal, n. 77, p. 5-25, août/déc. 1982. Disponível em: < http://iimarchives.org/wp-content/blogs.dir/ 
25/files/2017/06/inter77-alternative-\%C3\%A0-la-culture-moderne.pdf $>$. Acesso em: 4 fev. 2019.

Religion, philosophie et culture. Interculture. Montreal, n. 135, oct. 1998. Disponível em: < http://iimarchives.org/wp-content/blogs.dir/25/files/2017/ 06/inter135f-iim-et-sa-revue.pdf >. Acesso em: 6 fev. 2019.

Seria a noção de direitos humanos um conceito ocidental? In: BALDI, César Augusto (org.). Direitos humanos na sociedade cosmopolita. Rio de Janeiro: Renovar, 2004.

PARANÁ (Estado). Decreto n. 3.446, de 14 de agosto de 1997 (Diário Oficial n. 5067). Disponível em: < https://www.legislacao.pr.gov.br/legislacao/pesquisarAto.do?action= exibir\&codAto=54005\&indice $=1 \&$ totalRegistros $=1>$. Acesso em: 9 fev. 2019.

PEDRO I; PEDRO II. Fallas do Throno desde o anno de 1823 até o anno de 1889. Rio de Janeiro: Imprensa Nacional, 1889. Disponível em: < http://www2.senado.leg.br/bdsf/item/id/227319 >. Acesso em: 26 fev. 2019.

PEIRANO, Mariza. Etnocentrismo às avessas: o conceito de "sociedade complexa". Dados - Revista de Ciências Sociais, Rio de Janeiro, v. 26, n. 1, p. 97-115, 1983. Disponível em: < http://www.marizapeirano.com.br/artigos/1983_etnocentrismo_as avessas.pdf $>$. Acesso em 9 fev. 2019.

PENNA, Camila. Conexões e controvérsias no INCRA de Marabá: o Estado como um ator heterogêneo. Rio de Janeiro: Editora Garamond, 2014.

PEREIRA, Lafayette Rodrigues. Direito das coisas. 6. ed. São Paulo: Livraria Freitas Bastos, 1956.

PERLINGIERI, Pietro. Introduzione alla problematica della "proprietà". Roma: edizioni Scientifiche Italiane s.p.a., 2011.

PICCOLI, Emmanuelle.; MOTARD, Geneviève.; EBERHARD, Cristoph. Présentation : Les vies du pluralisme, entre l'anthropologie et le droit. Anthropologie et Sociétés, Quebec, v. 40, n. 2, p. 9-23, 2016. Disponível em: < https://www.erudit.org/en/journals/ as/2016-v40-n2-as02669/1037509ar/ >. Acesso em: 6 fev. 2019.

PILATTI, Adriano. A constituinte de 1987-1988: progressistas, conservadores, ordem econômica e regras do jogo. 2. ed. Rio de Janeiro: Editora Lumen Juris, 2016.

PINTO JÚNIOR, Jorge Modesto; FARIAS, Valdez Adriani. Função social da propriedade: dimensões ambiental e trabalhista. Brasília: Núcleo de Estudos Agrários e Desenvolvimento Rural, $2005 . \quad$ Disponível em: < http://www.reformaagrariaemdados.org.br/sites/default/files/pageflip-4204232-741451t_Funo_Social_da_Propri-985138.pdf >. Acesso em: 5 mar. 2019. 
POLANYI, Karl. A grande transformação. As origens de nossa época. Tradução de Fanny Wrobel. 2. ed. Rio de Janeiro: Elsevier Editora, 2012.

POLETTI, Ronaldo. Constituições brasileiras 1934. v. III. 3. ed. Brasília, 2012. Disponível em:

http://www2.senado.leg.br/bdsf/bitstream/handle/id/137602/Constituicoes_Brasileiras_v 3_1934.pdf?sequence $=10$ >. Acesso em: 5 fev. 2019.

PORTALIS, Jean-Étienne-Marie. De l'Usage et de l'abus de l'esprit philosophique durant le XVIIIe siècle. Tome I. 2ème. ed. Paris: Moutardier, 1827.

. De l'Usage et de l'abus de l'esprit philosophique durant le XVIIIe siècle. Tome II. 2ème. ed. Paris: Moutardier, 1827.

Discours préliminaire du premier projet de Code civil (1801). (Édition eletronique). Bordeaux: Éditions Confluences, 2004, 78 pp. (Collection Voix de la Cité). Disponível em: < http://mafr.fr/IMG/pdf/discours_1er_code_civil.pdf >. Acesso em: 26 fev. 2019.

PORTO-GONÇALVES, Carlos Walter. O desafio ambiental. Rio de Janeiro, Editora Record, 2004.

PORTUGAL. Ordenações Filipinas, Título XLIII, Livro Quarto, de 4 de abril de 1451. Disponível em: < http://www1.ci.uc.pt/ihti/proj/filipinas/14p822.htm >. Acesso em 24 fev. 2019.

PRADO JÚNIOR, Caio. Sentido da colonização. In: IGLÉSIAS, Francisco (org.). Caio Prado Júnior: história. São Paulo: Editora Ática, 1982.

QUEIROZ, Maria Isaura Pereira. O campesinato brasileiro. 2. ed. Petrópolis: Editora Vozes, 1976.

RENNER, Karl. Gli istituti del diritto privato e la loro funzione sociale. Traduzoine di Cornelia Mittendorfer. Bologna: Mulino, 1929.

REY, Alain. Signe. In: REY, Alain (org). Dictionnaire historique de la langue française. Paris: Robert, 1992 (verbete).

RITTSTIEG, Helmut. La proprietà come problema fondamentale. Studio sull'evoluzione del diritto mercantile. Traduzioni della Scuola di specializzazione in diritto civile dell Università di Camerino a cura di Pietro Perlingieri. Napoli: Edizioni Scientifiche Italiane, 2000.

ROULAND, Norbert. Anthropologie Juridique. Paris: Les Presses universitaires de France, 1988.

L'Anthropologie Juridique. (Que Sais-je ?). 2. Ed. Paris: Les Presses Universitaires de France, 1995. 
Pluralismo jurídico (Teoria antropológica). In: ARNAUD, André-Jean (Dir.). Dicionário enciclopédico de teoria e de sociologia do direito. Tradução de Patrice Charles, F. X. Willaume. 2. ed. Rio de Janeiro: Renovar, 1999. p. 589-590.

Nos confins do direito. Tradução de Maria Ermantina de Almeida Prado Galvão. São Paulo: Martins Fontes, 2008.

SACHS, Wolfgang. Diccionario del desarrollo. Una guía del conocimiento como poder. Perú: PRATEC, 1996. Disponível em: < https://www.uv.mx/mie/files/2012/10/SESION6-Sachs-Diccionario-Del-Desarrollo.pdf >. Acesso em: 18 fev. 2019

SAHLINS, Marshall. O "pessimismo sentimental" e a experiência etnográfica: por que a cultura não é um "objeto" em via de extinção (parte I). Mana, Rio de Janeiro, v. 3, n. 1, p. 41-73, abr. 1997. Disponível em: < http://www.scielo.br/pdf/mana/v3n1/2455.pdf $>$. Acesso em: 4 fev. 2019.

La nature humaine, une illusion occidentale. Réflexions sur l'histoire des concepts de hiérarchie et d'égalité, sur la sublimation de l'anarchie en Occident, et essais de comparaison avec d'autres conceptions de la condition humaine. Tradução do inglês por Olivier Renaut. Paris: Éditions de l'éclat, 2009.

SANTOS, Boaventura de Sousa. Renovar a teoria crítica e reinventar a emancipação social. São Paulo: Boitempo Editorial, 2007.

SANTOS, João Paulo de Farias. Reforma agrária e preço justo: a indenização na desapropriação agrária sancionatória. Porto alegre: Sérgio Antônio Fabris Editor, 2009.

SAUER, Sérgio. Terra e modernidade. A reinvenção do campo brasileiro. São Paulo: Expressão Popular, 2010.

SCAFF, Fernando Campos. A função social os imóveis agrários. Revista dos Tribunais, São Paulo, ano 94, v. 840, out. 2005, p. 107-113.

SCHMITZ, Arno Paulo; BITTENCOURT, Mauricio Vaz Lobo. O Estatuto da Terra no confronto do pensamento econômico: Roberto Campos versus Celso Furtado. Economia e Sociedade, Campinas, v. 23, n. 3, p. 577-609, dez. 2014. Disponível em: < http://www.scielo.br/pdf/ecos/v23n3/0104-0618-ecos-23-03-0577.pdf >. Acesso em: 26 fev. 2019.

SCHWARCZ, Lilia Mortiz. O espetáculo das raças: cientistas, instituições e questão racial no Brasil, 1870-1930. São Paulo: Cia. das Letras, 1993

SECRETO, Maria Verónica. Legislação sobre terras no Brasil do oitocentos: definindo a propriedade. Raízes, Campina Grande, v. 26, n. 1 e 2, p. 10-20, jan./dez. 2007. Disponível em: < http://revistas.ufcg.edu.br/raizes/artigos/Artigo_185.pdf >. Acesso em: 24 fev. 2019. 
SERRES, Michel. Habiter. Paris: Le Pommier, 2011.

SHANIN, Teodor. A definição de camponês: conceituações e desconceituações, o velho e o novo em uma discussão marxista. Revista Nera, Presidente Prudente-SP, ano 8, n. 1, p. 1-21, jul./dez. 2005. Disponível em: < http://www.scielo.br/scielo.php?script= sci_nlinks\&pid=S1414-753X201500020000 00013\&lng=en >. Acesso em: 9 fev. 2019.

SHIRLEY, Robert Weaver. Antropologia Jurídica. São Paulo: Saraiva, 1987.

SIGAUD, Lygia. Os clandestinos e os direitos: estudo sobre trabalhadores da cana-deaçúcar de Pernambuco. São Paulo: Duas Cidades, 1979.

SILVA, José Afonso da. Curso de direito constitucional positivo. 29. ed. São Paulo: Malheiros Editores, 2006.

Direito Ambiental Constitucional. 9. ed. São Paulo: Malheiros, 2011.

SILVA, José Gomes da. A Reforma Agrária no Brasil: frustração camponesa ou instrumento de desenvolvimento? Rio de Janeiro, Zahar, 1971.

. Reforma agrária e a Lei do Estatuto da Terra. Justitia, São Paulo, v. 44, n. 116,

$\begin{array}{lcccc}\text { p. } & 47-59, \quad \text { jan./mar., } & 1982 . & \text { Disponível } & \text { em: } \\ \text { http://www.revistajustitia.com.br/revistas/zwxcyz.pdf } & \text { >. Acesso em: } 14 \text { mar. } 2019 .\end{array}$

Caindo por terra: crises da Reforma Agrária na Nova República. São Paulo: Editora Busca Vida, 1987.

Buraco negro: a reforma agrária na Constituinte de 1987-1988. Rio de Janeiro: Paz e Terra, 1989.

SILVA, José Graziano da. Aos vencedores, as batatas. As implicações da vitória da UDR na Constituinte. In: MORAES, Sônia H. N. Guimarães; SILVA, José Gomes da; PORTO, Mayla Yara (org.). Re-construir a reforma agrária. Revista da Associação Brasileira de Reforma Agrária (ABRA). Campinas, ano 18 n. 2, p. 18-20, ago./nov. 1988.

SILVA, Ligia Osorio. Terras devolutas e latifúndio: efeitos da lei de 1850. 2. ed. Campinas: Editora Unicamp, 1996.

As Leis Agrárias e o Latifúndio Improdutivo. São Paulo em Perspectiva, São Paulo, v. 11, n. 2, p. 15-25, 1997. Disponível em: < https://pt.scribd.com/document/167422016/Ligia-Osorio-Silva-Leis-Agrarias-e-oLatifundio-Improdutivo >. Acesso em: 26 fev. 2019.

Latifúndio. In: MOTTA, Márcia (org.). Dicionário da terra. Rio de Janeiro: Civilização Brasileira, 2010, p. 272-276.

SILVA, Lígia Osório; SECRETO, María Verónica. Terras públicas, ocupação privada: elementos para a história comparada da apropriação territorial na Argentina e no Brasil. Economia e Sociedade, Campinas, n.12, p. 109-141, jun. 1999. Disponível em: < file:///C:/Users/julia/Downloads/06_ligia.pdf >. Acesso em: 24 fev. 2019. 
SIRVINSKAS, Luís Paulo. Direito Ambiental. 10. ed. São Paulo: Saraiva, 2012.

SMITH, Roberto. Propriedade da terra \& transição: estudo da formação da propriedade privada da terra e transição para o capitalismo no Brasil. 2. ed. São Paulo: Editora Brasiliense, 2008.

SODERO, Fernando Pereira. Conceito de Estatuto: O Estatuto da Terra. Justitia, São Paulo, v. 44, n. 116, p. 9-14, jan./mar. 1982.

SOUZA LIMA, Antonio Carlos. "Dossiê Fazendo Estado" 2002, Revista de Antropologia $U S P$, n. 2, v. 55, jul./dez. 2012, São Paulo, 559-832.

STAUT JÚNIOR. Sérgio Said. Dimensão jurídica e formas de apropriação no Brasil. Revista da Faculdade de Direito - UFPR, Curitiba, n. 47, p.29-64, 2008.

STEDILE, João Pedro (org). A questão agrária no Brasil. Programas de reforma agrária - 1946-2003. 2. ed. São Paulo: Editora Expressão Popular, 2012.

SUPIOT, Alain. Homo juridicus. Ensaio sobre a função antropológica do Direito. Tradução de Maria Ermantina de Almeida Prado Galvão. São Paulo: Martins Fontes, 2007.

TAYLOR, Charles. Multiculturalismo. Examinando a política de reconhecimento. Tradução de Marta Machado. Lisboa: Instituto Piaget, 1998.

TERENCE, Marcelo Fernando. Avanços e limites da reforma agrária no sul do Pará: um estudo a partir do projeto de assentamento Canarana. 2013. $211 \mathrm{f}$. Dissertação (Mestrado em Geografia Humana) - Faculdade de Filosofia, Letras e Ciências Humanas, Universidade de São Paulo, São Paulo, 2013. Disponível em: < http://www.teses.usp.br/teses/disponiveis/8/8136/tde-28082013-

130807/publico/2013_MarceloFernandoTerence_VCorr.pdf >. Acesso em: 10 mar. 2019.

TIMSIT, Gérard. L'archipel de la norme. Paris: Les Presses Universitaires de France, 1997.

THOMPSON, Edward Palmer. Senhores \& Caçadores. Tradução Denise Bottmann. Rio de Janeiro: Paz e Terra, 1987.

URBINATI, Inoã Pierre Carvalho. Latifúndio inabalável. Revista de História da Biblioteca Nacional, Rio de Janeiro, v. 1, p. 80-83, 2015. Disponível em: < http://www.dmtemdebate.com.br/latifundio-inabalavel/ >. Aceso em 26 fev. 2019.

VACHON, Robert. L'Etude du Pluralisme Juridique. Une Approche Diatopique et Dialogale. The Journal of Legal Pluralism and Unofficial Law, London, v. 22, n. 29, p. 163-173, 1990. Disponível: < https://www.tandfonline.com/doi/abs/10.1080/07329113. $\underline{\text { 1990. } 10756419}$ >. Acesso em: 4 fev. 2019. 
Le mythe émergent du pluralisme et de l'interculturalisme de la réalité. In:

Séminaire I Pluralisme et Société, Discours alternatifs à la culture dominante, Montreal: l'Institut Interculturel de Montréal, févr. 1997. 39 p. Disponível em < http://www.dhdi.free.fr/recherches/horizonsinterculturels/ articles/vachonpluralism.pdf >. Acesso em: 4 fev. 2019.

L'Iim et as Revue. Une alternative interculturelle et um interculturel alternative. Interculture. Montreal, n. 135. oct. 1998. Disponível em: < http://iimarchives.org/wp-content/blogs.dir/25/files/2017/06/inter135f-iim-et-sarevue.pdf >. Acesso em: 4 fev. 2019.

VANDERLINDEN, Jacques. Vers une nouvelle conception du pluralisme juridique. Revue de la recherche juridique, droit prospectif. Presses Universitaires d'AixMarseille, Marseille, v. 53, n. 18, p. 573-583, 1993.

Anthropologie juridique. Paris: Dalloz, 1996.

Qu'est-ce qu'un code ?. Les Cahiers de droit, v. 46, n. 1-2, p. 29-51, 2005. Disponível em: < https://www.erudit.org/fr/revues/cd1/2005-v46-n1-2$\underline{\operatorname{cd} 3841 / 043827 \mathrm{ar} /}$ >. Acesso em :13 mar. 2019.

. Les pluralismes juridiques. In: CHRÉTIEN-VERNICOS, Geneviève; RUDEANTOINE, Edwige (dir.). Anthropologies et Droits. Etats des savoirs et orientations contemporaines. Paris: Dalloz, 2009.

VEIGA, José Eli da. O que é reforma agrária. 14. ed. São Paulo: Editora Brasiliense, 1994.

Mundo em Transe: Do Aquecimento Global ao Ecodesenvolvimento. Campinas, SP: Armazém do Ipê, 2009

VILLAS BÔAS FILHO, Orlando. A constituição do campo de análise e pesquisa da antropologia jurídica. Prisma Jurídico, São Paulo, v. 6, p. 333-349, 2007. Disponível em: < http://www.redalyc.org/articulo.oa? id=93400620 >. Acesso em: 4 fev. 2019.

Teoria dos sistemas e o direito brasileiro. São Paulo: Saraiva, 2009.

Juridicidade: uma crítica à monolatria jurídica como obstáculo epistemológico. Revista da Faculdade de Direito da USP, São Paulo v. 109, p. 281-325,, jan./dez. 2014. Disponível em: < http://www.revistas.usp.br/rfdusp/article/view/89235 >. Acesso em: 6 fev. 2019.

A regulação jurídica para além de sua forma ocidental de expressão: uma abordagem a partir de Étienne Le Roy. Revista Direito \& Práxis, Rio de Janeiro, v. 6, n. 12, p. 159-195, 2105. Disponível em: < www.e-publicacoes.uerj.br/index.php/ revistaceaju/article/download/16050/14088 >. Acesso em: 6 fev. 2019.

A juridicização e o campo indigenista no Brasil: uma abordagem interdisciplinar. Revista da Faculdade de Direito USP, São Paulo, v. 111, p. 339-379, 
jan./dez. 2016a. Disponível em: < http://www.revistas.usp.br/rfdusp/article/ view/133516 >. Acesso em: 6 fev. 2019.

Apresentação. In.: STANICH NETO, Paulo (org.). Direito das comunidades tradicionais caiçaras. São Paulo: Editora com Lei, 2016 b.

Antropologia jurídica. In: CAMPILONGO, Celso Fernandes; GONZAGA, Alvaro de Azevedo; FREIRE, André Luiz (coord.). Enciclopédia jurídica da PUC-SP. Tomo: Teoria Geral e Filosofia do Direito. 1. ed. São Paulo: Pontifícia Universidade Católica de São Paulo, 2017. Disponível em: < https://enciclopediajuridica.pucsp.br/verbete/42/edicao-1/antropologia-juridica $>$. Acesso em: 4 fev. 2019.

WANDERLEY, Maria de Nazareth Baudel. Um saber necessário: os estudos rurais no Brasil. Campinas: Editora Unicamp, 2011.

WEBER, Max. Ensaios de Sociologia. Tradução de Waltensir Dutra. 5. ed. Rio de Janeiro: Editora LTC, 1979.

WELCH, Cliff. Propriedade. In: MOTA, Márcia (org.). Dicionário da terra. 2. ed. Rio de Janeiro: Editora Civilização Brasileira, 2010.

WOOD, Ellen Meiksins. As origens agrárias do capitalismo. Traduzido por Lígia Osório Silva. Crítica Marxista, v. 50, n. 3, jul./ago. 1998. Disponível em: < https://www.ifch.unicamp.br/criticamarxista/arquivos_biblioteca/artigo6612_merged.pd f >. Acesso em: 24 fev. 2019.

WOODMAN, Gordon R.; BURMAN, Sandra. Folk Law. In: ARNAUD, André-Jean (Dir.). Dicionário enciclopédico de teoria e de sociologia do direito. Tradução de Patrice Charles, F. X. Willaume. 2. ed. Rio de Janeiro: Renovar, 1999, p. 353-356.

WOORTMANN, Ellen F. Herdeiros, parentes e compadres. Colonos do sul e sitiantes do Nordeste. São Paulo-Brasília: Hucitec e EDUNB, 1995.

Campesinato e posse da terra. In: LIMA, Antônio Carlos de (org.). Antropologia \& Direito. Tema antropológicos para estudos jurídicos. Rio de Janeiro; Brasília: LACED; Associação Brasileira de Antropologia, 2012. p. 336-345. 